\title{
Ammonium glycyrrhizin counteracts liver injury caused by lipopolysaccharide/amoxicillin-clavulanate potassium
}

\author{
Zugong Yu ${ }^{1}$, Feng Wu${ }^{1}$, Jing Tian ${ }^{1}$, Xuewen Guo ${ }^{1}$, Ran An ${ }^{1}$ and Yangyang Guo ${ }^{1}$ \\ ${ }^{1}$ Laboratory of Veterinary Pharmacology and Toxicology, College of Veterinary Medicine, Nanjing Agricultural University, \\ Nanjing, Jiangsu Province, 210095, China
}

Correspondence to: Zugong Yu, email: yuzugong@njau.edu.cn

Keywords: lipopolysaccharide, amoxicillin clavulanate potassium, chicken primary hepatocytes, compound ammonium glycyrrhizin, antioxidant

Received: November 02, 2016

Accepted: May 07, 2017

Published: May 30, 2017

Copyright: Yu et al. This is an open-access article distributed under the terms of the Creative Commons Attribution License 3.0 (CC BY 3.0 ), which permits unrestricted use, distribution, and reproduction in any medium, provided the original author and source are credited.

\section{ABSTRACT}

We treated isolated chicken primary hepatocytes with lipopolysaccharide/ amoxicillin clavulanate potassium (LPS/AC) to model liver injury and investigate its underlying mechanisms. We also used this model to assess the cytoprotective effects of compound ammonium glycyrrhizin (CAG) in vitro. LPS/AC-induced injury decreased cell viability and increased the activity of serum aspartate transaminase and alanine transaminase. Levels of superoxide dismutase, glutathione, and glutathione peroxidase were lower than control, while levels of the oxidative product malondialdehyde and reactive oxygen species were higher. Treatment with CAG for $24 \mathrm{~h}$ ameliorated these changes. Caspase-3 activity assays and flow cytometry revealed increased apoptosis in the model group. However, apoptosis decreased after CAG treatment, as confirmed by Hoechst 33342 staining. We also observed changes in mitochondrial ultrastructure. Real-time PCR and western blot analyses showed that CAG treatment downregulated LPS/AC-induced RNA expression of caspase-3, caspase-9, bax, cytochrome $c$, and fas, and upregulated the expression of bcl-2. Mitochondrial cytochrome c was released into the cytosol and the inner mitochondrial membrane potential $(\Delta \Psi \mathrm{m})$ was decreased. Our results highlight CAG as a potential therapeutic agent to counteract LPS/AC-induced liver injury.

\section{INTRODUCTION}

Lipopolysaccharide (LPS), a cell wall component of gram-negative bacteria [1], is capable of eliciting inflammatory responses that involve the release of numerous proinflammatory cytokines, thereby leading to hepatic necrosis and a decrease in the levels of antioxidant enzymes and free radical scavengers $[2,3]$. In humans, the injection of nanograms of LPS into the bloodstream can result in septic shock [4], whereas its administration to animals induces symptoms of liver injury.

From 1995 to 2005,77 out of 1,164 cases $(6.6 \%$ incidence) in an outpatient hepatology clinic involved liver injury, which is commonly associated with the use of drugs [5]. Serious drug-induced liver injury may lead to hospitalization, and it is the most common identifiable cause of acute liver failure in the US $[6,7]$. Antibacterial agents and other drugs are another frequent cause of liver failure after transplantation, autoimmune hepatitis, and drug-induced liver injury (DILI) [8-10]. It is reported that from 2004 to 2007 , antibacterial agents including amoxicillin/ clavulanic acid, third-generation cephalosporins, and fluoroquinolones, accounted for $45.5 \%$ of DILI in the US [11-13]. DILI arises via complex multistep mechanisms, which are initiated by chemical insults to liver cells. Formation of chemically reactive metabolites, impairment of mitochondrial function, inhibition of the activity of the bile salt export pump 
(BSEP) and/or other biliary efflux transporters are some of the major processes that trigger DILI [14].

Amoxicillin/clavulanic acid is one of the most frequently used antibiotic combinations in both human and veterinary clinical practice [15]. Nonetheless, when amoxicillin is used alongside a $\beta$-lactamase inhibitor such as clavulanic acid, the risk of hepatotoxicity and liver injury is increased [16-18]. It is reported that amoxicillin clavulanate $(\mathrm{AC})$ is a type of penicillin strongly associated with hepatotoxicity and is the most frequent cause of DILI-related hospitalizations in clinical medicine [19].

Gram-negative bacteria are common pathogens that attack chickens. Multiple antibiotics, particularly bactericidal drugs, have been used in high doses and frequencies in veterinary clinics [20]. LPS and AC can each lead to hepatic injury, and studies have shown that AC potassium induces the release of LPS. Glycyr1rhizic acid (GA) or glycyrrhizin is commonly used in Asia to treat patients with chronic hepatitis [21-23]. Compound ammonium glycyrrhizin (CAG), which is mainly composed of glycyrrhizin, glycine, and methionine, is an effective anti-inflammatory, anti-cancer, anti-hepatotoxic, and antioxidant drug [24-28].

Here, we used cultured chicken liver primary cells to investigate whether the release of LPS due to AC potassium administration aggravates hepatocyte injury. We created a chicken primary hepatocyte model to explore the mechanisms underlying liver damage by LPS/AC and to determine whether CAG imparts a protective effect. Using this model, we measured various anti-oxidative indicators such as superoxide dismutase (SOD), reduced glutathione (GSH), glutathione peroxidase (GSH-Px), reactive oxygen species (ROS), and malondialdehyde (MDA). We also measured alanine transaminase (ALT) and aspartate transaminase (AST) activity in liver cells, the percentage of apoptotic cells, and the expression levels of various mRNAs and proteins related to the apoptosis and p38 pathways.

\section{RESULTS}

\section{Isolation and culture of chicken primary hepatocytes}

Inverted phase contrast microscopy indicates that the hepatocytes that were isolated at an early stage were elliptical and circular in shape. Most of the hepatocytes adhered to the bottom of the culture plate at $6 \mathrm{~h}$ after plating. At $24 \mathrm{~h}$ of culture, the cells had fused and differentiated to form islands on the plate. At 9 days of culture, roughly half of the cells had undergone apoptosis, and the remaining cells showed cytoplasmic granulation (Figure 1).

\section{Effect of LPS/AC treatment on hepatocytes}

LPS/AC treatment of hepatocytes (Figure 2) resulted in variations in cell viability and morphology. Treatment of cells with $30+60 \mu \mathrm{g} / \mathrm{mL}$ and $30+80 \mu \mathrm{g} / \mathrm{mL}$ LPS/AC did not induce changes in cellular morphology, although their relative cell viability was $81.52 \pm 2.35 \%$ and $75.54 \pm 2.79 \%$, respectively. At a concentration of $30+100 \mu \mathrm{g} / \mathrm{mL}$, the observed cell viability of the hepatocytes was $53.56 \pm 6.17 \%$ and their shape was irregular, with disruption of the cell membrane. Exposure of the cells to $30 \mu \mathrm{g} / \mathrm{mL}$ of LPS $+140 \mu \mathrm{g} / \mathrm{mL}$ of AC led to a great reduction in the total number of hepatocytes. The application of $30 \mu \mathrm{g} / \mathrm{mL}$ of LPS $+100 \mu \mathrm{g} / \mathrm{mL}$ of AC caused the death of $50 \%$ of the cells; therefore, this was deemed the most appropriate concentration in the model groups.

\section{CAG attenuates LPS/AC-induced acute liver injury in hepatocytes}

The cells were divided into five groups: The control group neither received CAG nor LPS/AC; the model group was exposed to $30 \mu \mathrm{g} / \mathrm{mL}$ of LPS $+100 \mu \mathrm{g} / \mathrm{mL}$ of AC for $24 \mathrm{~h}$; and the combination group was treated with $30 \mu \mathrm{g} / \mathrm{mL}$ of LPS $+100 \mu \mathrm{g} / \mathrm{mL}$ of $\mathrm{AC}$ for $24 \mathrm{~h}$ after the addition of 1,10 , or $100 \mu \mathrm{g} / \mathrm{mL}$ of CAG. Figure $3 \mathrm{~A}$ shows that the activity of the cells was almost half of that of the control when exposed to $30 \mu \mathrm{g} / \mathrm{mL}$ of LPS $+100 \mu \mathrm{g} / \mathrm{mL}$ of $\mathrm{AC}$ for $24 \mathrm{~h}(51.23 \pm 2.46 \%)$. However, cell viability reached $85.88 \pm 3.03 \%$ and $93.37 \pm 1.80 \%$, respectively, when treated with $10 \mu \mathrm{g} / \mathrm{mL}$ and $100 \mu \mathrm{g} / \mathrm{mL}$ of CAG. The activity of both ALT and AST was significantly lower compared to that in the LPS/AC group $(P<0.01$, Figure 3B-3C).

\section{Effect of CAG on the levels of SOD, GSH, GSH- Px, MDA, and ROS in hepatocytes}

Figure 4 shows that the administration of LPS/AC for $24 \mathrm{~h}$ led to a decrease $(P<0.01)$ in the activity of GSH, GSH-Px, and SOD to $26.18 \pm 3.08 \mathrm{nmol} / \mathrm{mg}$ protein, $16.11 \pm 0.30$, and $40.63 \pm 2.05 \mathrm{U} / \mathrm{mg}$ protein, respectively, compared to that in the control group (GSH: $59.64 \pm 4.45$ $\mathrm{nmol} / \mathrm{mg}$ protein; GSH-Px: $46.22 \pm 0.08 \mathrm{U} / \mathrm{mg}$ protein; and SOD: $79.05 \pm 9.72 \mathrm{U} / \mathrm{mg}$ protein). Furthermore, treatment with LPS/AC resulted in an increase in MDA and ROS levels. Treatment with CAG $(10,100 \mu \mathrm{g} / \mathrm{mL})$ for $24 \mathrm{~h}$ resulted in an increase in SOD, GSH, and GSHPx activity $(P<0.05)$, and a decrease in MDA and ROS levels $(P<0.01)$. Together, these findings suggest that CAG treatment protects hepatocytes from LPS/ACinduced acute liver injury in vitro. 

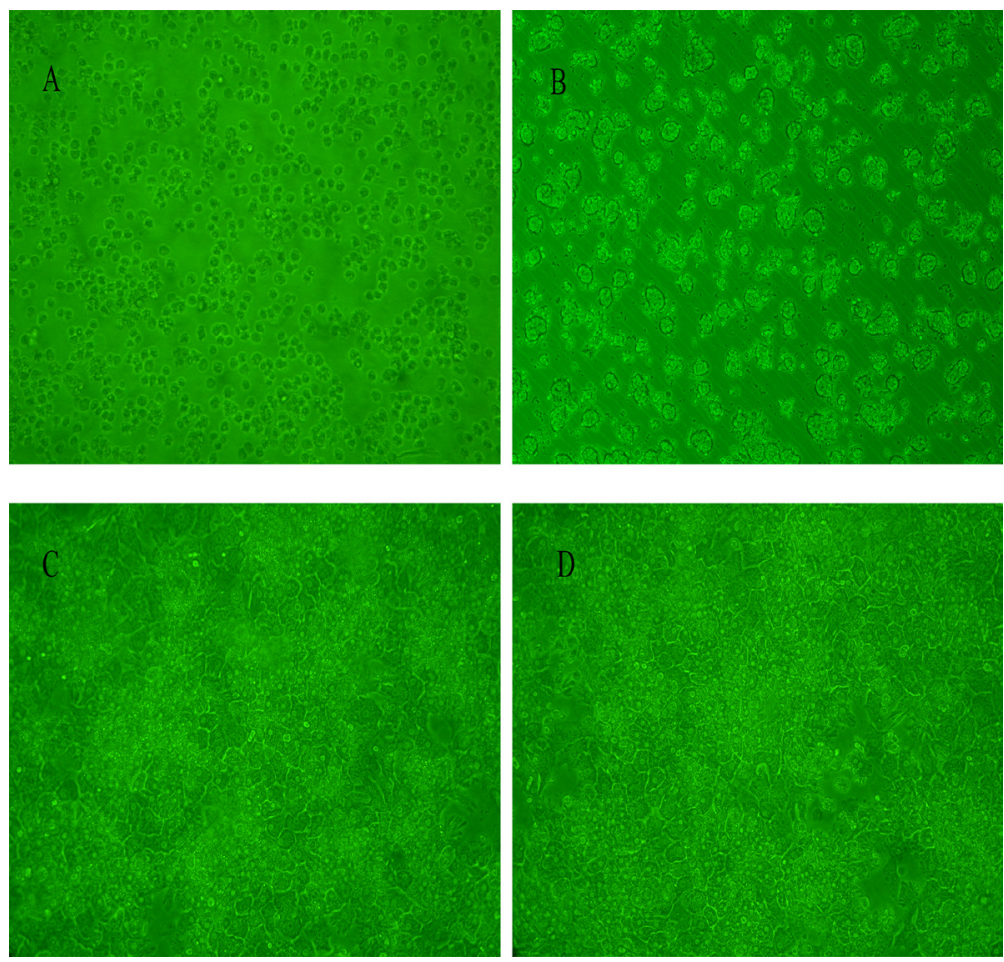

Figure 1: Cell viability assay for cultured chicken hepatocytes. (A) Graph indicating that cell viability was $\sim 90 \%$. (B) Image showing that most hepatocytes cultured for $6 \mathrm{~h}$ adhered to the bottom of the culture plate. $(\mathbf{C}-\mathbf{D})$ Hepatocytes cultured at $24 \mathrm{~h}$ and $48 \mathrm{~h}$, exhibiting differentiation into irregular polygonal shapes.

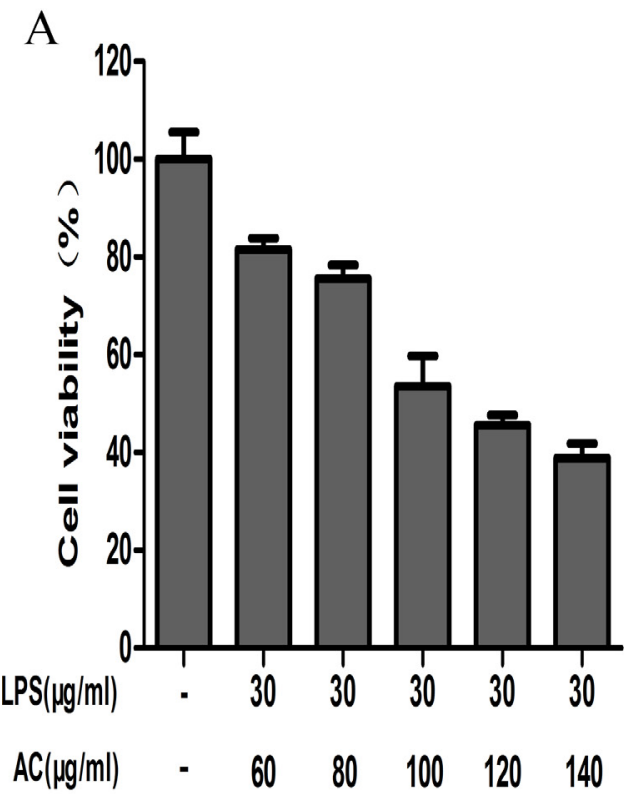

$\mathrm{B}$
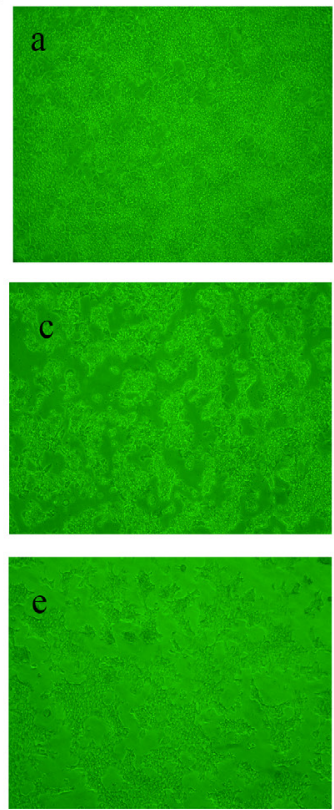
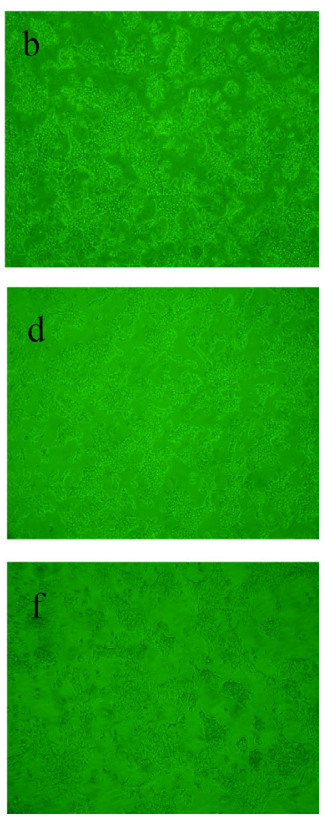

Figure 2: Effects of LPS/AC treatment on hepatocytes. (A) Variations in hepatocyte viability after LPS/AC treatment for 24 h. MTT assay showing that LPS/AC treatment induces a decrease in cell viability in a dose-dependent manner. Values are expressed as the mean $\pm \mathrm{SD}(n=3)$ and the IC50 was $30 \mu \mathrm{g} / \mathrm{mL}$ of LPS $+100 \mu \mathrm{g} / \mathrm{mL}$ of AC. (B) Effect of different concentrations of LPS/AC treatment (24 h) on hepatocyte cytomorphology as visualized with an inverted phase-contrast microscope (20×). a: Normal cells; b: $30 \mu \mathrm{g} / \mathrm{mL}$ of LPS $+60 \mu \mathrm{g} / \mathrm{mL}$ of AC; c: $30 \mu \mathrm{g} / \mathrm{mL}$ of LPS $+80 \mu \mathrm{g} / \mathrm{mL}$ of AC; $\mathrm{d}: 30 \mu \mathrm{g} / \mathrm{mL}$ of LPS $+100 \mu \mathrm{g} / \mathrm{mL}$ of AC; e: $30 \mu \mathrm{g} / \mathrm{mL}$ of LPS $+120 \mu \mathrm{g} / \mathrm{mL}$ of AC; f: $30 \mu \mathrm{g} / \mathrm{mL}$ of LPS $+140 \mu \mathrm{g} / \mathrm{mL}$ of AC. 


\section{Measurement of caspase- 3 activity by using a colorimetric assay}

The exposure of hepatocytes to LPS/AC for $24 \mathrm{~h}$ resulted in an increase in the activity of caspase-3 (OD: $0.344)$ compared to that in the control group (OD: 0.179) $(P<0.01)$. Moreover, the caspase-3 activity of hepatocytes exposed to CAG (1 and $10 \mu \mathrm{g} / \mathrm{mL}$ ) (OD: 0.291, 0.287) significantly decreased $(P<0.05)$ compared to that in the model group that was exposed to a high concentration of CAG $(100 \mathrm{mg} / \mathrm{mL}, P<0.01$, Figure $4 \mathrm{D})$.

\section{Apoptosis rates of the LPS/AC and CAG groups as assessed by FCM}

The percentage of apoptotic cells was higher in the LPS/AC group than in the control group $(P<0.05)$. On the other hand, the percentage of apoptotic cells in the groups exposed to 1,10 , or $100 \mu \mathrm{g} / \mathrm{mL}$ of CAG was lower than that in the model group (Figure 5).

\section{Assessment of apoptotic cells by Hoechst 33342 staining}

Compared to the control group, a more intense blue fluorescence due to Hoechst 33342 staining highlighting apoptotic cells was observed in the model group. However, after the exposure of the hepatocytes to $100 \mu \mathrm{g} / \mathrm{mL} \mathrm{CAG}$ for $24 \mathrm{~h}$, the rate of apoptosis decreased (Figure 6).

\section{CAG modifies the level of mRNA expression in hepatocytes}

At the transcriptional level, the application of $30 \mu \mathrm{g} / \mathrm{mL}$ of LPS $+100 \mu \mathrm{g} / \mathrm{mL}$ of AC triggered an increase in the expression of caspase-3, caspase-9, bax, Fas, and cyt c by $1.94 \pm 0.13$-fold, $4.88 \pm 1.8$-fold, $1.97 \pm 0.24$ fold, $2.32 \pm 0.21$-fold, and $5.01 \pm 0.56$, respectively, and a decrease in bcl- 2 expression of $0.60 \pm 0.05$-fold in the hepatocytes, compared to levels in the control group. We did not observe differences in the levels of bcl-2 and fas mRNA expression between the model group and the groups treated with CAG at concentrations of 1 and $10 \mu \mathrm{g} / \mathrm{mL}$. However, treatment with $100 \mu \mathrm{g} / \mathrm{mL}$ of CAG did result in decreased mRNA levels of bcl-2 and fas in hepatocytes compared to those in the model group $(P<0.05$, Figure 7$)$.

\section{Impact of CAG on LPS/AC-induced protein expression of caspase-3, caspase-9, bax, cyt c, and bcl-2}

The level of bax, caspase-3, and caspase-9 protein expression increased in the LPS/AC group compared to that in the control group and decreased in the presence
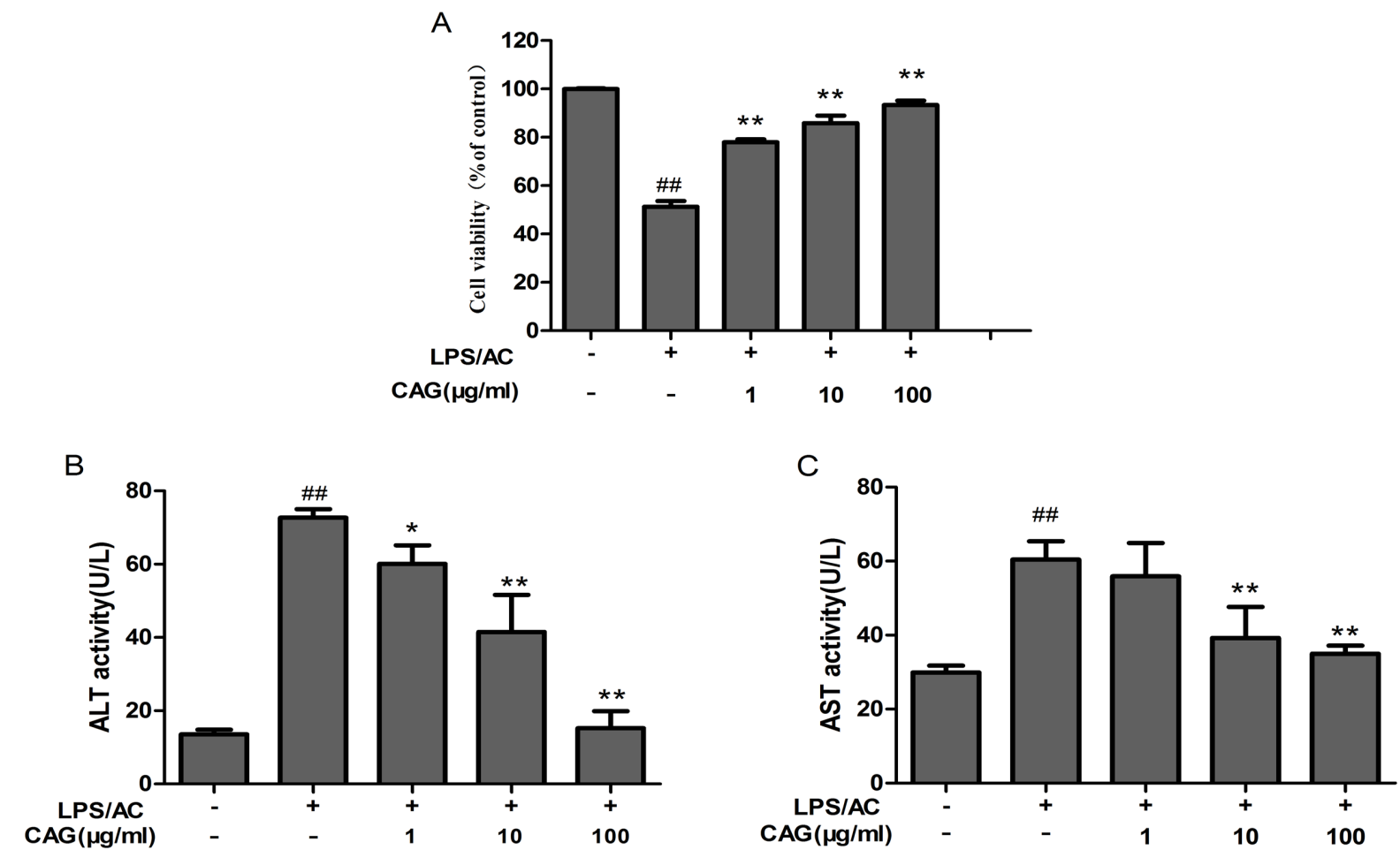

Figure 3: The effects of CAG on (A) cell viability, (B) alanine transaminase (ALT) activity, and (C) aspartate transaminase (AST) activity. The hepatocytes were treated with $30 \mu \mathrm{g} / \mathrm{mL}$ of LPS $+100 \mu \mathrm{g} / \mathrm{mL}$ of AC after exposure to CAG for $24 \mathrm{~h}$. For the LPS/AC-treated groups, "-" and "+" represent the cells in culture medium and those treated with $30 \mu \mathrm{g} / \mathrm{mL}$ of LPS $+100 \mu \mathrm{g} / \mathrm{mL}$ of AC, respectively. For the CAGtreated groups, "-" represent cells treated without CAG. Values are expressed as the mean \pm SD. $(n=3)$. $<0.05$, $\#<0.01$ compared to the control; $*<0.05, * *<0.01$ compared to the model. 
of CAG relative to that in the model group (Figure 8). However, bcl-2 levels decreased in the LPS/AC group compared to those in the control group and increased in the CAG groups compared to those in the model group. The expression of cyt $\mathrm{c}$ was increased in the cytoplasm but decreased in mitochondria when cells were treated with LPS/AC. However, cyt c expression was decreased in the cytoplasm and increased in mitochondria compared with the model group when the concentration of CAG was $100 \mu \mathrm{g} / \mathrm{mL}$ (Figure 10).

\section{Ultrastructural changes in hepatocytes}

The cells of the control group showed normal ultrastructural features, including a smooth round nucleus
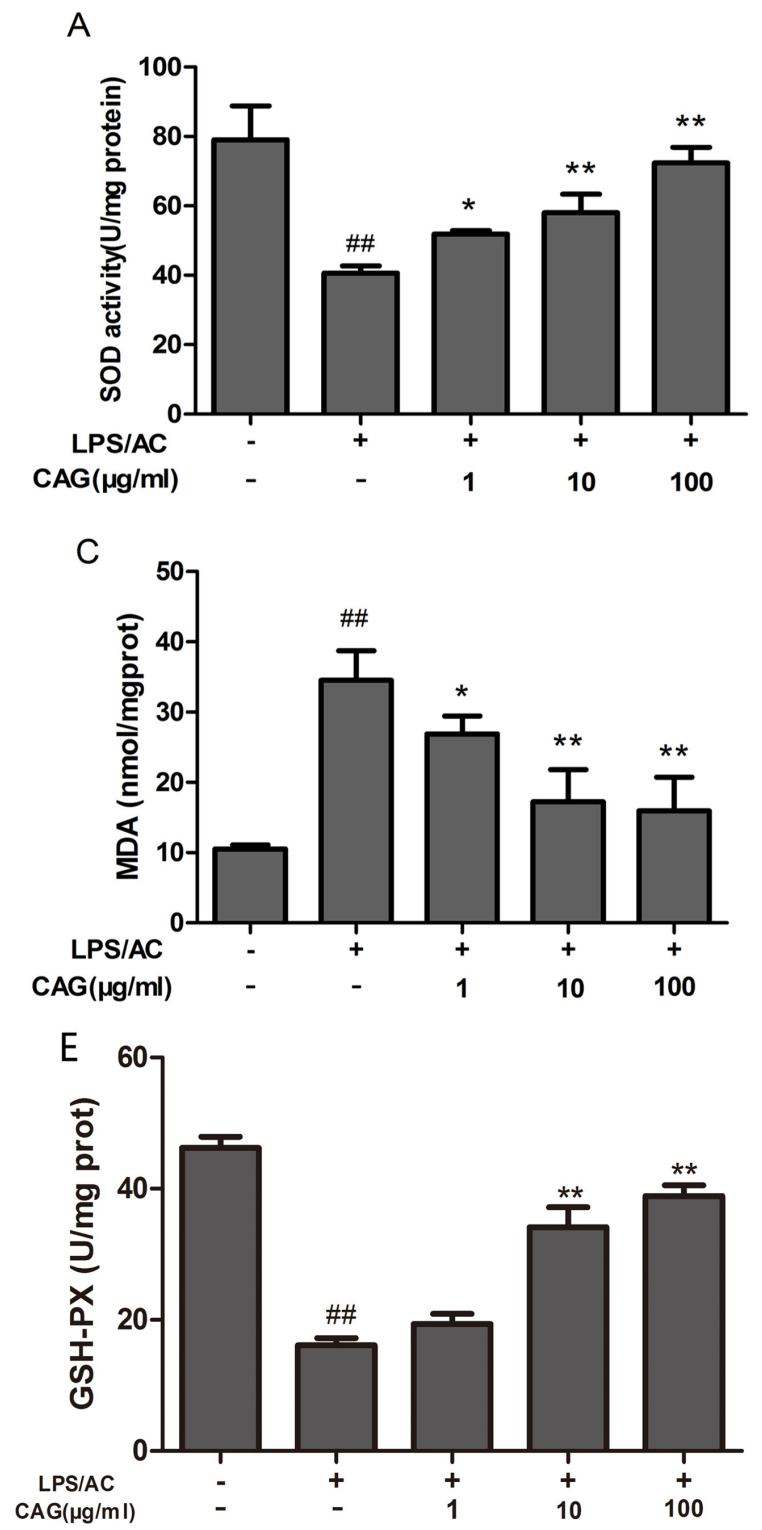

with the nuclear membrane intact, and mitochondria with normal cristae (Figure 9). The mitochondria of liver cells from the LPS/AC treatment group were swollen, vacuolated, and exhibited disintegration or loss of cristae.

\section{Effect of LPS/AC on mitochondrial membrane potential}

The $\Delta \Psi \mathrm{m}$ (mitochondrial membrane potential) of chicken liver cells was analyzed using JC-1. Normal mitochondria initially fluoresced red, and then green as $\Delta \Psi \mathrm{m}$ become lower. The treatment group showed increased green fluorescence compared with the control group. Furthermore, green fluorescence decreased upon treatment with CAG at $100 \mu \mathrm{g} / \mathrm{mL}$ (Figure 11).

B
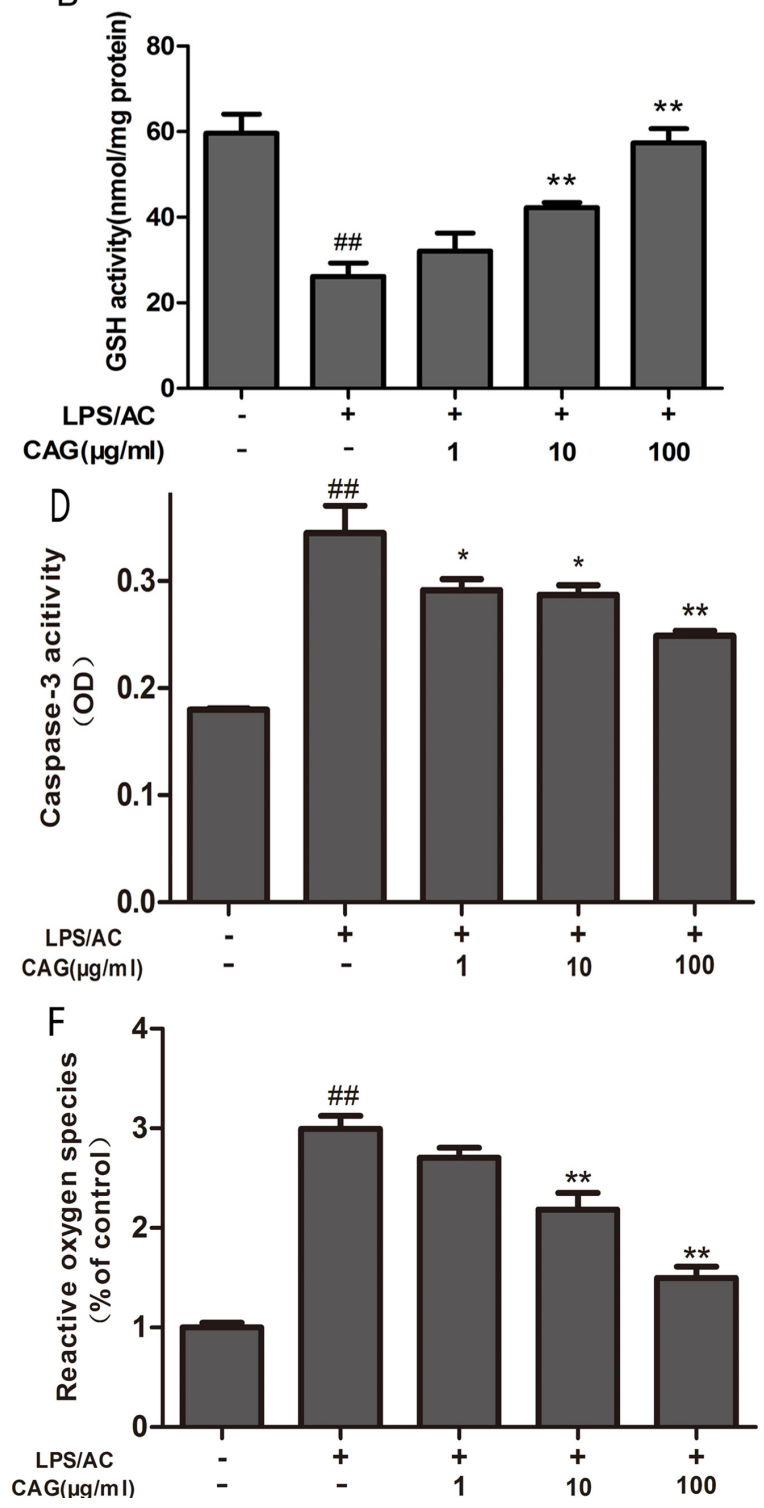

Figure 4: Effects of the CAG treatment on the levels of oxidative stress, cellular antioxidant enzymes, and caspase-3 activity. (A) SOD, (B) GSH, (C) MDA, (D) caspase-3, and (E) GSH-Px activity, and (F) reactive oxygen species (ROS) levels in the supernatant. Values are expressed as the mean $\pm \mathrm{SD}$. $(n=3) .{ }^{\#}<0.05,{ }^{\#}<0.01$ compared to the control; $*<0.05, * *<0.01$ compared to the model. 


\section{DISCUSSION}

The objective of the present study was to explore the effect of LPS/AC in hepatocytes and to determine whether CAG could reverse such effect. We found that LPS/AC causes hepatocyte injury and that $\mathrm{CAG}$ can reverse it. In our experiments, cells treated with LPS/AC showed decreased viability, decreased ALT and AST activity, increase in the levels of oxidative stress indicators, increased apoptosis, and alterations in the expression levels of apoptosis-related mRNAs and proteins.

We used a modified two-step IV collagenase ex-situ perfusion method that was based on an in situ method to isolate primary hepatocytes as a predictor of
A

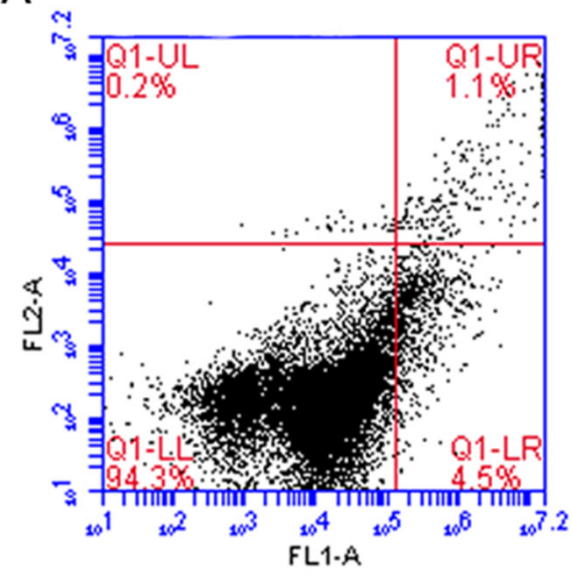

C

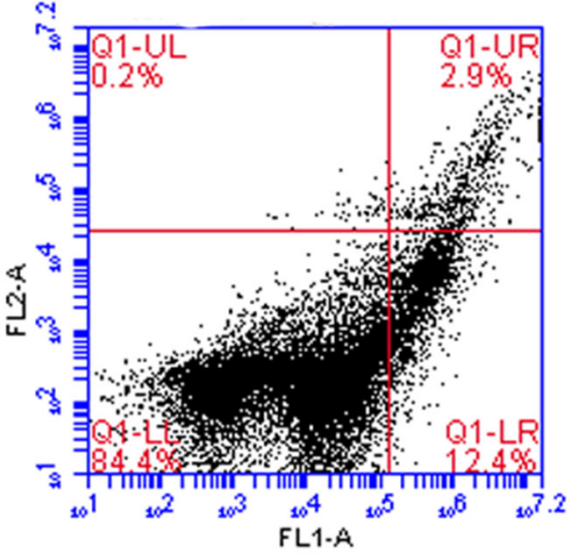

E

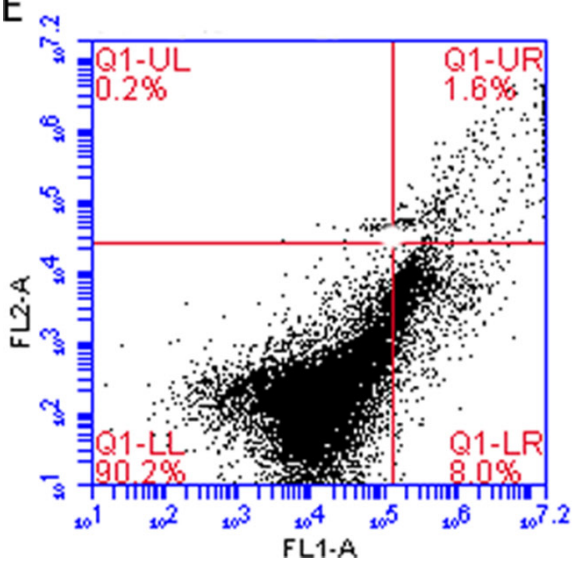

B

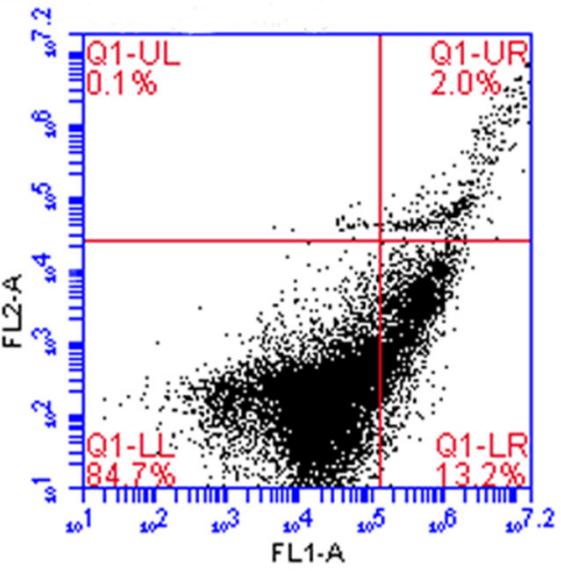

$\mathrm{D}$

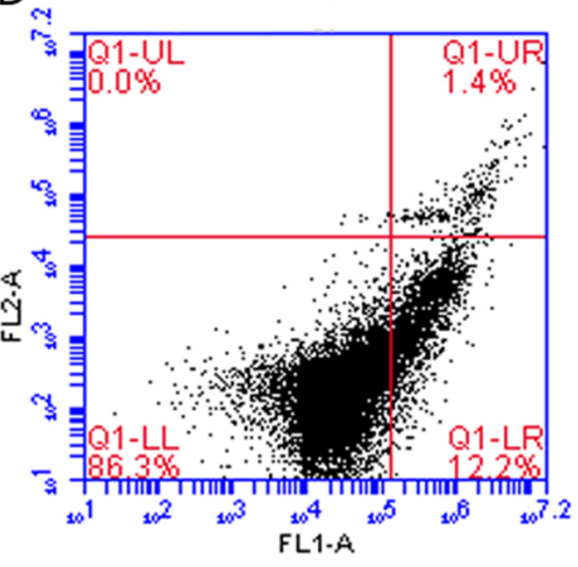

$\mathrm{F}$

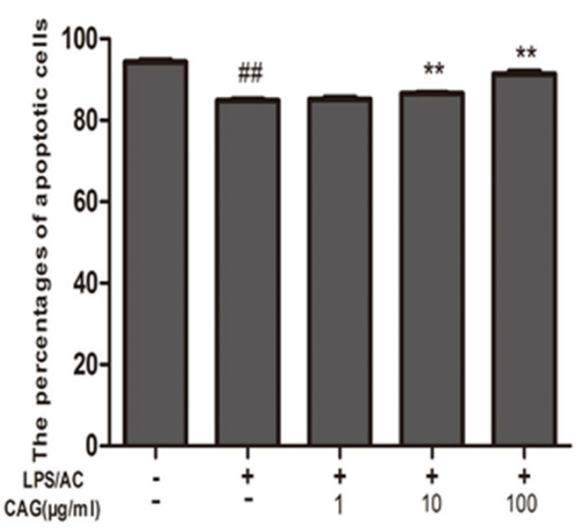

Figure 5: Changes in apoptosis rate in chicken primary hepatocytes as determined by FCM. Change in the percentage of apoptotic cells for (A) control group, (B) model group, (C) $1 \mu \mathrm{g} / \mathrm{mL}$ CAG treatment group, (D) $10 \mu \mathrm{g} / \mathrm{mL}$ CAG treatment group, and (E, F) $100 \mu \mathrm{g} / \mathrm{mL} \mathrm{CAG}$ treatment group. ${ }^{*}<0.05,{ }^{\#}<0.01$ compared to the control; $*<0.05, * *<0.01$ compared to the model group. 

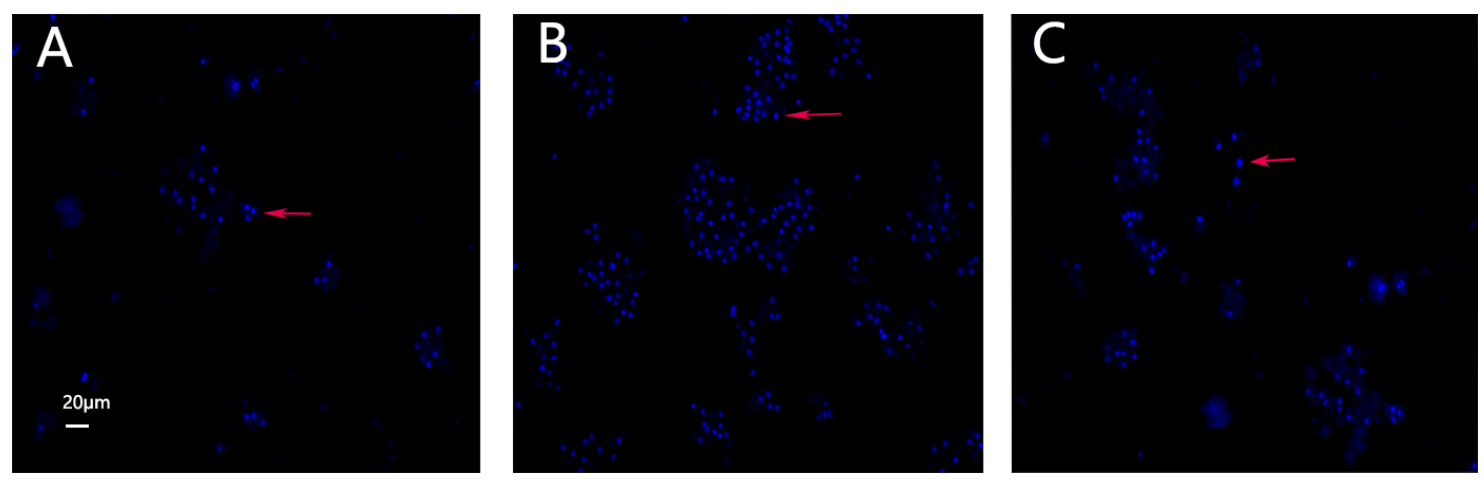

Figure 6: Hoechst 33342 staining. Images of cultured hepatocytes stained with Hoechst 33342. (A) Control, (B) model, and (C) $100 \mu \mathrm{g} / \mathrm{mL}$ CAG treatment groups.
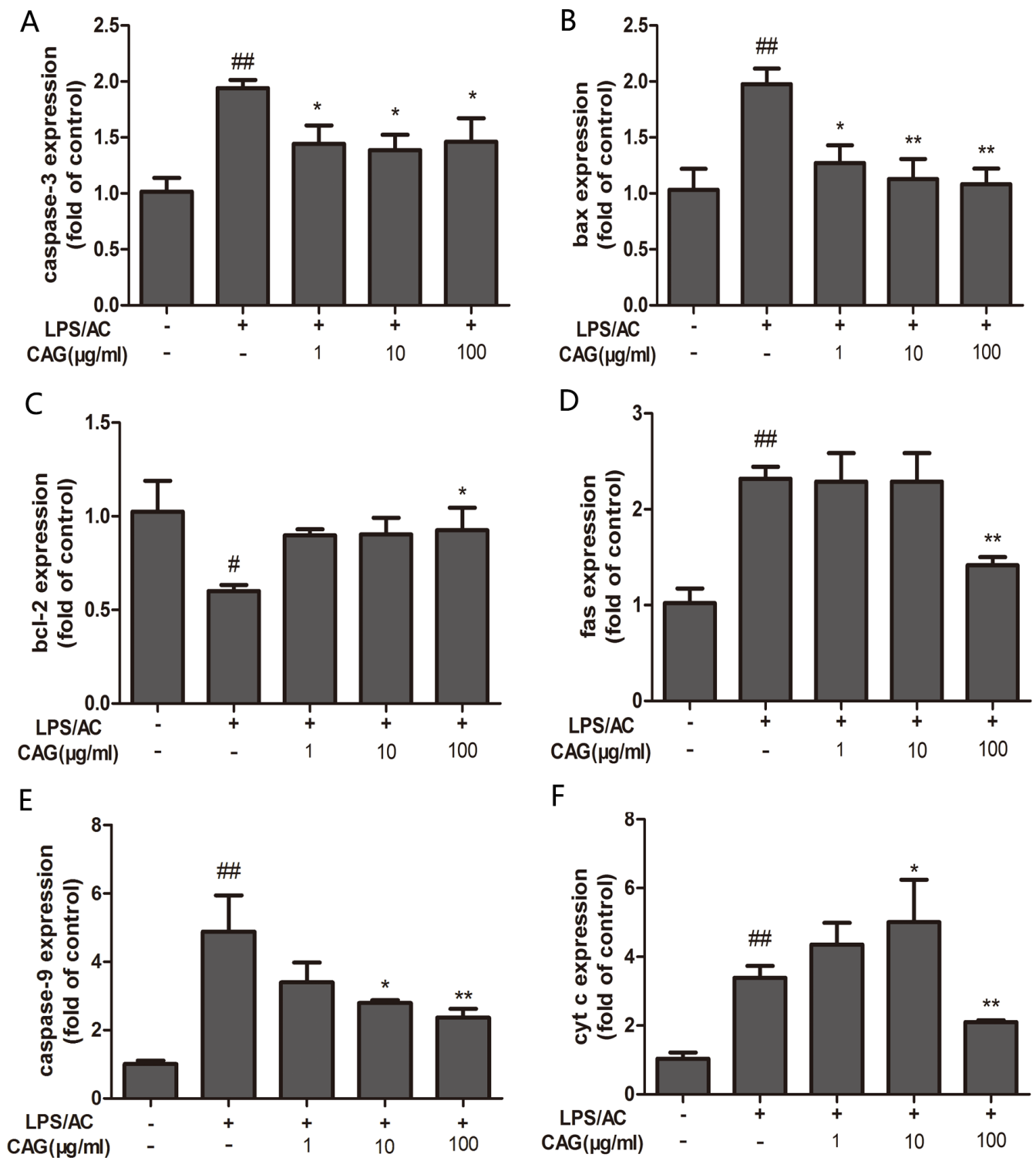

Figure 7: Effect of CAG on LPS/AC-induced changes in the expression of apoptosis-related genes in hepatocytes. $\beta$-actin was used as a reference. mRNA expression of (A) caspase-3, (B) bax, (C) bcl-2, (D) fas, (E) caspase-9, and (F) cytochrome c. The $2^{-\Delta \Delta \mathrm{Ct}}$ method was used to quantify the expression levels of each gene. Values are expressed as the mean $\pm \mathrm{SD}(n=3)$. ${ }^{\#<0.05}$, ${ }^{\# \prime<0.01}$ compared to the control; $*<0.05, * *<0.01$ compared to the model. 
liver responses $[29,30]$. Our hepatocytes showed a high level of dispersion, purity, and viability (90\%) in culture for approximately nine days (Figure 1). This allowed us to assess enzyme induction and inhibition and perform medium-throughput screening of compounds.

LPS and AC have each been shown to induce liver injury $[18,31]$. A composite liver injury model using LPS and Bacillus Calmette-Guerin or D-galactosamine has been previously established [32-34]; however, no reports employing LPS in combination with AC to induce liver injury are currently available. In our previous study, we determined the optimal LPS and AC doses that induce liver injury in vitro, as well as their respectively $\mathrm{IC}_{50}$, which was $60 \mu \mathrm{g} / \mathrm{mL}$ and $180 \mu \mathrm{g} / \mathrm{mL}$, respectively. On this basis, treatment of hepatocytes with LPS/AC resulted in a concentration-dependent increase in cell death, with an $\mathrm{IC}_{50}$ of $30+100 \mu \mathrm{g} / \mathrm{mL}$, which indicates that the dose of LPS required to generate a combined $\mathrm{AC}$ induced liver injury was much lower than that required when these are modeled separately (Figure 2). Reports have shown that LPS can induce hepatocyte damage in rat primary hepatocytes at a dose of $40 \mu \mathrm{g} / \mathrm{mL}$ [35]. The dose we found to induce liver injury in chicken hepatocytes was thus higher than that in rats. This suggests that rat liver cells are more sensitive to LPS than chicken cells. However, when we exposed chicken hepatocytes to a combination of AC potassium and LPS, the concentration of LPS necessary to induce injury was lower than that in rats.

The present study reveals that the activity of ALT and AST in the cell culture medium of the model groups was higher than in controls (Figure 3). This suggests that LPS/ AC causes hepatic structural damage since ALT and AST are normally localized in the cytoplasm and are released into the circulation only after cellular damage [36].

In our investigation, we treated hepatocytes with different doses of CAG after exposure to $30 \mu \mathrm{g} / \mathrm{mL}$ of LPS $+100 \mu \mathrm{g} / \mathrm{mL}$ of AC (Figure 3A). Results from our cell viability assays indicate that viability increased in a dosedependent manner and was accompanied by an increase in the activity of ALT and AST in the supernatant (Figure 3). These results indicate that LPS/AC can induce liver injury in vitro, and that $\mathrm{CAG}$ can reverse this effect.

Oxidative stress can also activate signaling pathways, thereby causing cell damage $[37,38]$. MDA, which is produced by free radical-mediated lid peroxidation, is frequently used as a marker of oxidative stress. In contrast, SOD, GSH, and GSH-Px protect host cells from oxidative damage by scavenging free radicals. Figure 4 shows an increase in MDA levels and a decrease in SOD activity, as well as a decrease in the concentration of GSH and GSH$\mathrm{Px}$ in cell lysate collected from the model group. This suggests that LPS/AC triggers oxidative damage to the cell membranes of hepatocytes, in agreement with previous studies [39]. Furthermore, glycyrrhizin effectively inhibits lid peroxidation and enhances the capacity to eliminate free-radicals [28]. In addition, CAG inhibited LPS/ACinduced liver injury by increasing SOD activity and GSH levels and decreasing MDA levels (Figure 4), which may be attributable to its free-radical scavenging power. ROS can induce cell death and activate various signaling
A

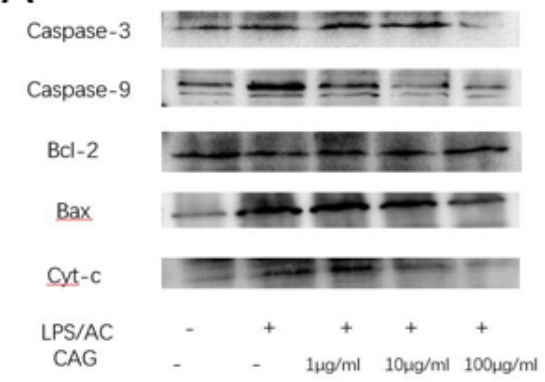

D

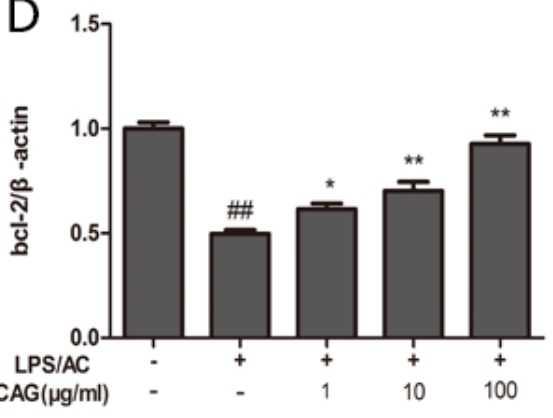

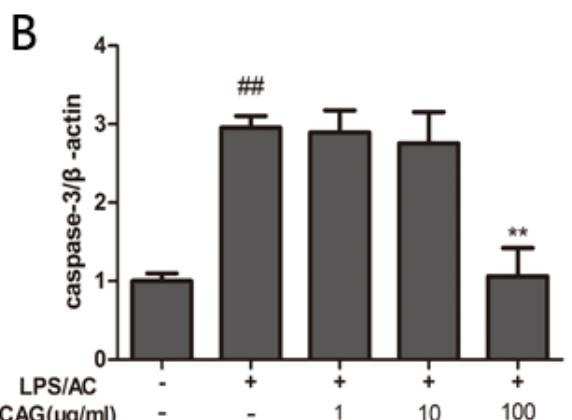

E

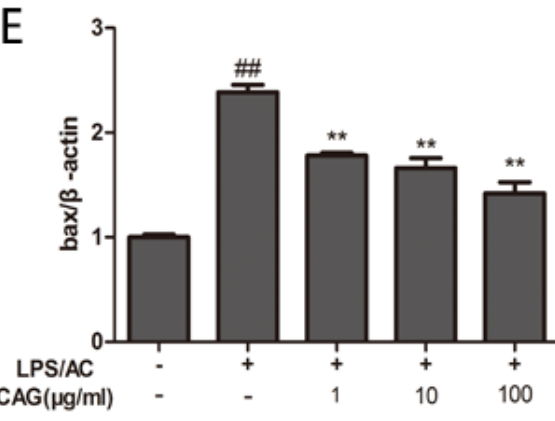

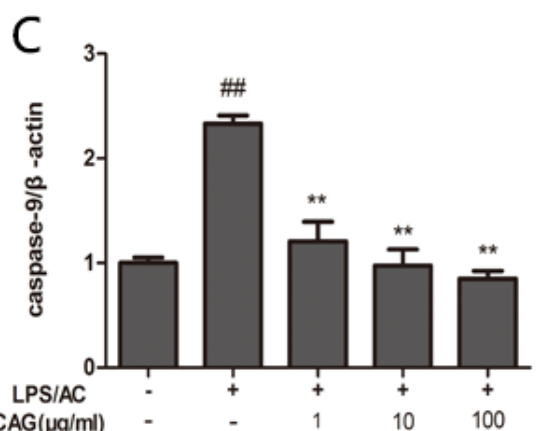

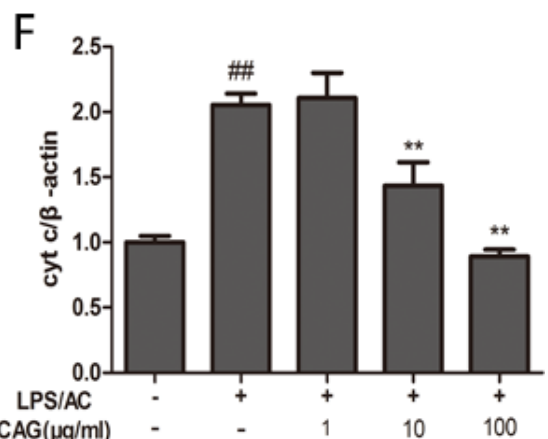

Figure 8: Effect of CAG on LPS/AC-induced changes in the expression of apoptosis-related proteins in hepatocytes. (A) western blot bands, (B) caspase-3, (C) caspase-9, (D) bcl-2, (E) bax, and (F) cytochrome c. $\beta$-actin was used as reference. Bands analyzed by ImageJ. The data are expressed as the mean $\pm \mathrm{SD}(n=3) .{ }^{\#<0.05, ~}{ }^{\#}<0.01$ compared to the control; $*<0.05, * *<0.01$ compared to the model group. 
pathways [40]. Our study here we showed that CAG could decrease ROS induced by LPS/AC in hepatocytes.

Apoptosis in hepatocytes can occur in virus- or nonvirus-induced acute liver injury [41, 42] and is the main mechanism hallmark of liver failure [43].
To determine whether LPS/AC induces apoptosis in hepatocytes and whether CAG reverses this event, we measured the rate of apoptosis in cultured hepatocytes by FCM and Hoechst 33342 staining (Figures 5 and 6). Both experiments showed an increase in the number of
A1

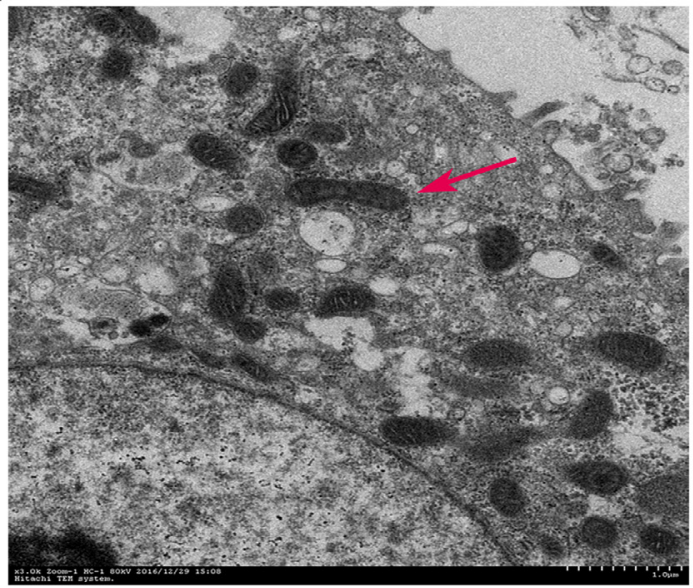

A2

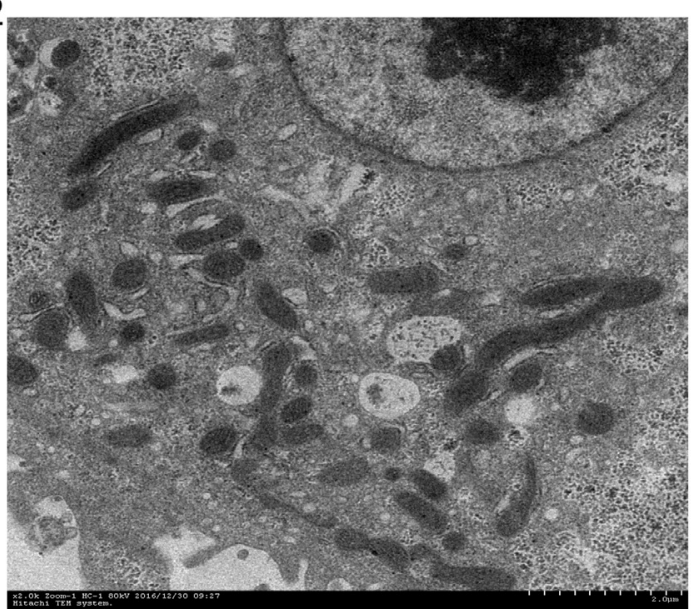

B1

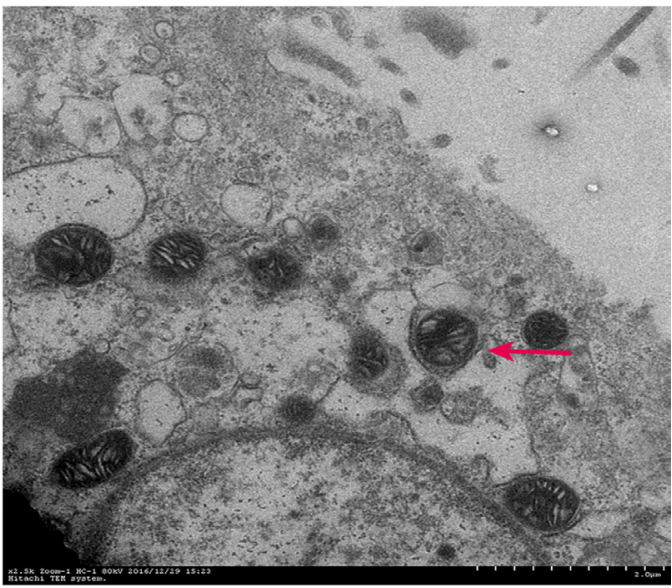

B2

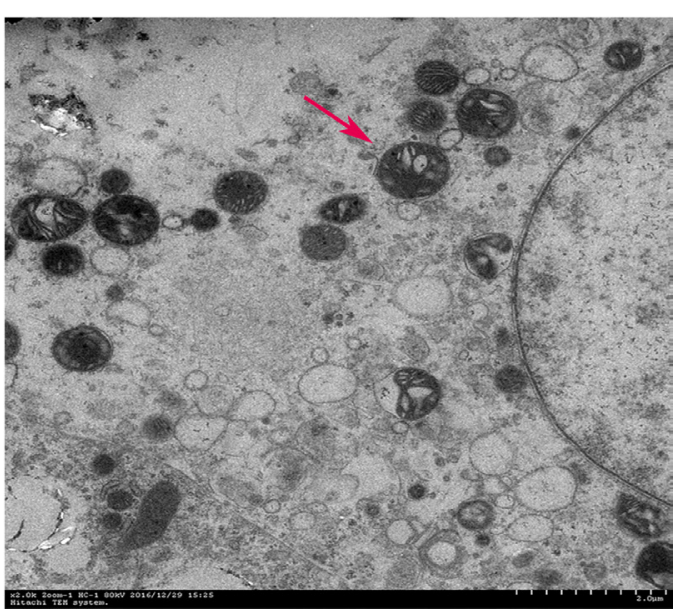

Figure 9: Ultrastructural features of chicken primary hepatocytes. (A) Control and (B) model groups. Arrows point to mitochondria.

A

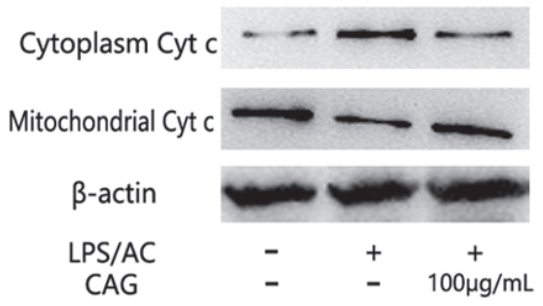

B

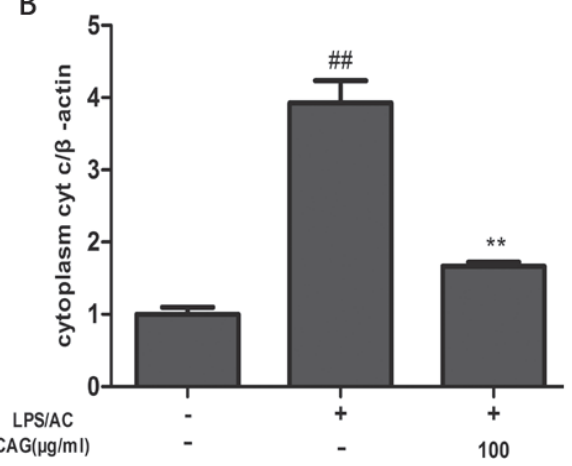

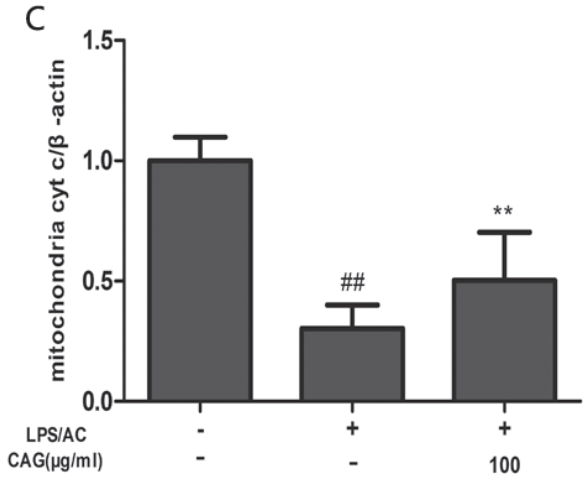

Figure 10: Effect of CAG on LPS/AC-induced changes in the expression of cytoplasmic and mitochondrial cyt $\mathrm{c}$ in hepatocytes. (A) western blot bands, (B) cytoplasm cyt, and (C) mitochondria cyt c. $\beta$-actin was used as a reference. Bands analyzed by ImageJ. The data are expressed as the mean $\pm \mathrm{SD}(n=3)$. ${ }^{\#}<0.01$ compared to control group; $* *<0.01$ compared to the model group. 
apoptotic hepatocytes after LPS/AC treatment. However, when CAG was added into the medium, cellular repair was observed in a dose-dependent manner.

The inter-membranous space of mitochondria contains various pro-apoptotic proteins, which include cytochrome c, AIF, and endonuclease G (EndoG). Mitochondrial swelling and release of cytochrome occur during permeabilization of the outer mitochondrial membrane [44-46]. Cytochrome c associates with the adaptor protein Apaf-1 and the prodomain protein caspase-9 to form the apoptosome complex, which in turn initiates apoptosis [47, 48]. Caspase-3, which is a key executor of apoptosis, is then activated. Our results indicated that the mRNA and protein levels of caspase-3 increased after LPS/AC injection, whereas this was markedly attenuated by CAG (Figures 7 and 8). In our experiments, LPS/AC treatment also induced an increase in the mRNA and protein levels of caspase-9, cyt c, and bax, which in turn may be responsible for inducing apoptosis in primary hepatocytes. Furthermore, mitochondria became swollen and $\Delta \Psi \mathrm{m}$ decreased in model group. Similarly, western blot analyses showed that cyt $\mathrm{c}$ was released from mitochondria into the cytoplasm (Figures 9, 10 and 11).

The bcl-2 family includes pro-apoptotic (bax and bid) or anti-apoptotic (bcl-2 and bcl-xl) proteins that regulate the mitochondrial apoptotic pathway. In addition, these proteins also regulate cell survival and death by blocking both the death receptor and mitochondrial apoptosis pathways [49]. Bcl-2 and bax have opposite effects on cell death: Bcl-2 inhibits or delays cell death, whereas bax accelerates apoptosis [50]. Our results here suggest that the increase in bax mRNA and protein levels and the decrease in Bcl-2 levels correlate with LPS/AC-
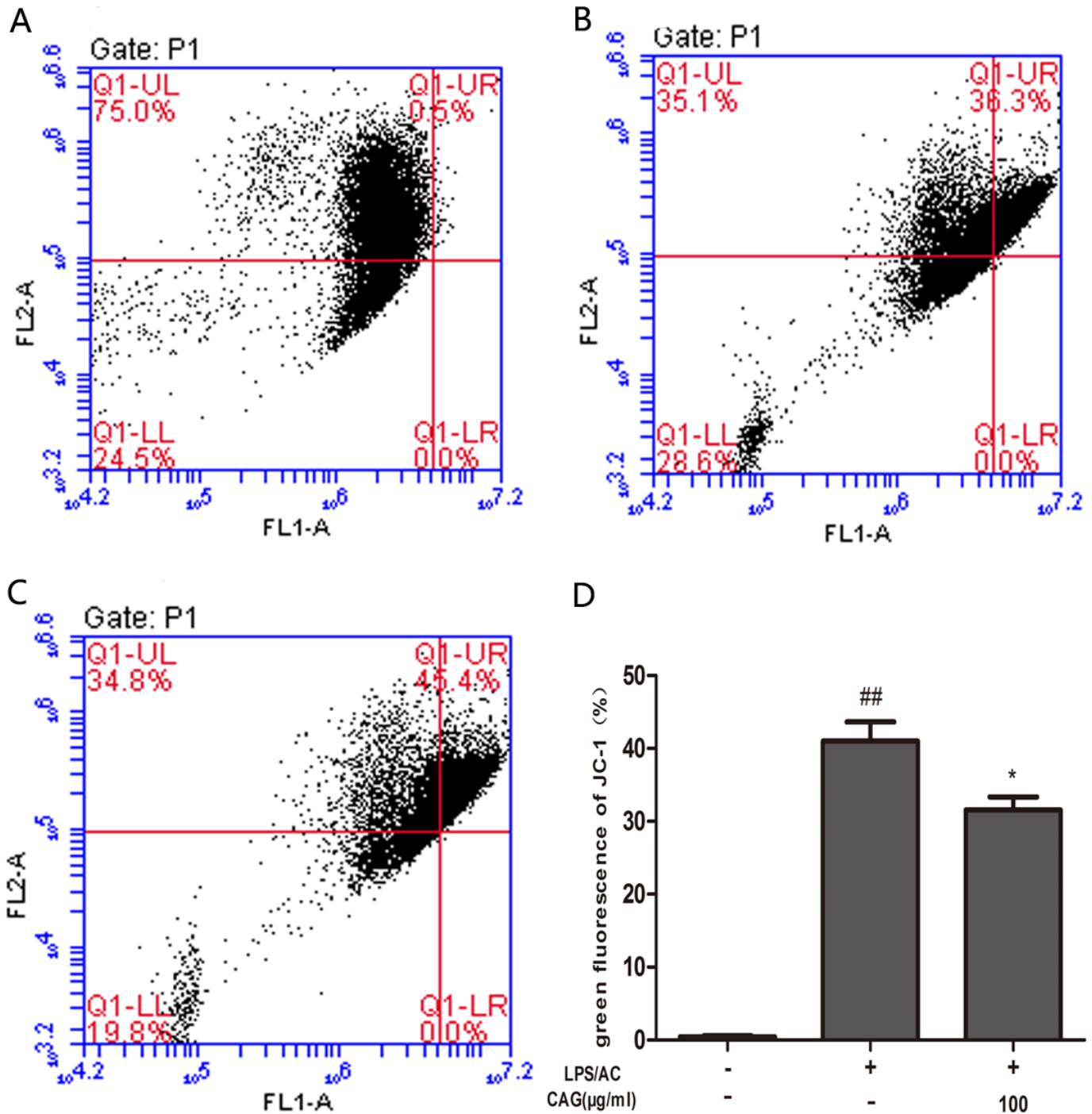

D

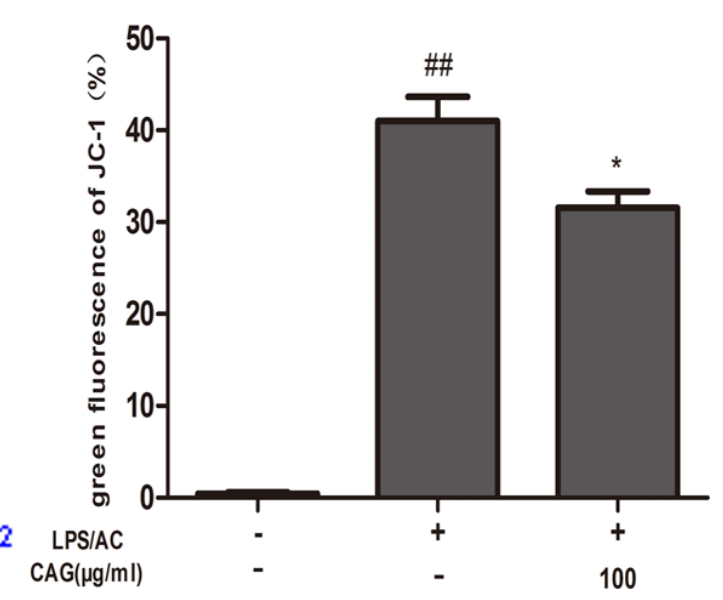

Figure 11: Effect of CAG on LPS/AC-induced changes in the mitochondrial membrane potential of chicken liver hepatocytes. $\Delta \Psi \mathrm{m}$ was measured in the (A) control group, (B) model group, (C) $100 \mu \mathrm{g} / \mathrm{mL}$ CAG treatment group. (D) Percentage of green fluorescence. The data are expressed as the mean $\pm \mathrm{SD}(n=3) .{ }^{\#}<0.01$ compared to the control group; $*<0.05$ compared to the model group. 
induced apoptosis (Figures 7-8), in agreement with studies reporting that the bax/bcl-2 ratio increases with apoptosis [51]. The administration of $100 \mu \mathrm{g} / \mathrm{mL}$ of CAG attenuated bax mRNA and protein expression, suggesting that CAG has a protective effect against LPS/AC-induced liver injury.

The p38 MAPK pathway transduces a variety of extracellular signals that transmit cellular responses to stress, and is implicated in cell proliferation, differentiation, and apoptosis $[52,53]$. In the present study, we observed an increase in the rate of phosphorylation of p38 kinases after exposure to LPS/AC, an effect that was reversed after CAG treatment (Figure 12). The hepatoprotective activity of CAG may thus be due to the inhibition of LPS/ACinduced phosphorylation of p38 MAPKs.

In conclusion, this is the first model that depicts LPS/ $\mathrm{AC}$-induced chicken liver injury in vitro and the beneficial effects of CAG treatment. The mechanism of action of $\mathrm{CAG}$ as a protective agent involves the maintenance of the level of cellular antioxidants, inhibition of apoptosis, and regulation of the $\mathrm{p} 38$ MAPK signaling cascade in liver cells. Therefore, our study shows that AC potassium enhances the toxicity of LPS in chicken hepatocytes whereas CAG administration may be used an alternative therapy to treat or prevent acute hepatic damage.

\section{MATERIALS AND METHODS}

\section{Reagents and materials}

CAG was prepared in our laboratory. Collagenase (type IV), LPS (E. coli L-2880) and HPEPS were purchased from Sigma Chemical Co. Dulbecco's modified eagle's medium (DMEM) was obtained from Hyclone. Diagnostic kits used to determine the presence or absence of AST, ALT, SOD, GSH, and MDA were obtained from Nanjing Jiancheng Institute of Biotechnology (Nanjing, China).

\section{Preparation and incubation of isolated hepatocytes}

Hepatocytes were isolated from male Hailan chickens (average weight: $1.0-1.5 \mathrm{~kg}$ ) by using a twostep collagenase perfusion method. The chickens were anesthetized by using a cocktail of xylazine $(2 \mathrm{mg} / \mathrm{mL})$ and ketamine $(20 \mathrm{mg} / \mathrm{mL})$, and their livers were excised after ligating the hepatic blood vessels such as the pancreaticoduodenal veins, the mesenteric vein, and the inferior caval vein. We then cut a ventage in the portal vein and inserted a tubule to allow perfusion of saline solution A (33 mM/L HEPES, $127.8 \mathrm{mM} / \mathrm{L} \mathrm{NaCl}, 3.15 \mathrm{mM} / \mathrm{L} \mathrm{KCl}$, $0.7 \mathrm{mM} / \mathrm{L} \mathrm{Na} \mathrm{HPO}_{4} \cdot 12 \mathrm{H}_{2} \mathrm{O}, 0.6 \mathrm{mM} / \mathrm{L}$ EGTA, $\mathrm{pH} 7.4$ ) that was warmed to $37^{\circ} \mathrm{C}$ to wash out the blood. Then, to remove the EGTA, perfusion was performed using saline solution $\mathrm{B}$ (solution $\mathrm{A}$ added $3 \mathrm{mM} / \mathrm{L} \mathrm{CaCl}_{2}, \mathrm{pH}$ 7.4) at room temperature and at a flow rate of $10-20 \mathrm{~mL} / \mathrm{min}$ for $15 \mathrm{~min}$. Finally, the liver was perfused in a beaker with $0.5 \%$ collagenase IV at a flow of $20 \mathrm{~mL} / \mathrm{min}$ for 20-25 min at $37^{\circ} \mathrm{C}$. Hepatocytes were separated from other cellular components by centrifugation at $50 \mathrm{~g}$ for $3 \mathrm{~min}$ and the precipitates were resuspended in DMEM containing $10 \%$ fetal bovine serum (FBS, Gibco), $0.5 \mathrm{mg} / \mathrm{L}$ bovine insulin, $100 \mathrm{U} / \mathrm{mL}$ penicillin, and $0.25 \mathrm{mg} / \mathrm{mL}$ streptomycin ( $\mathrm{pH}$ 7.4). Hepatocytes were counted using a hemocytometer, and cell viability was determined using
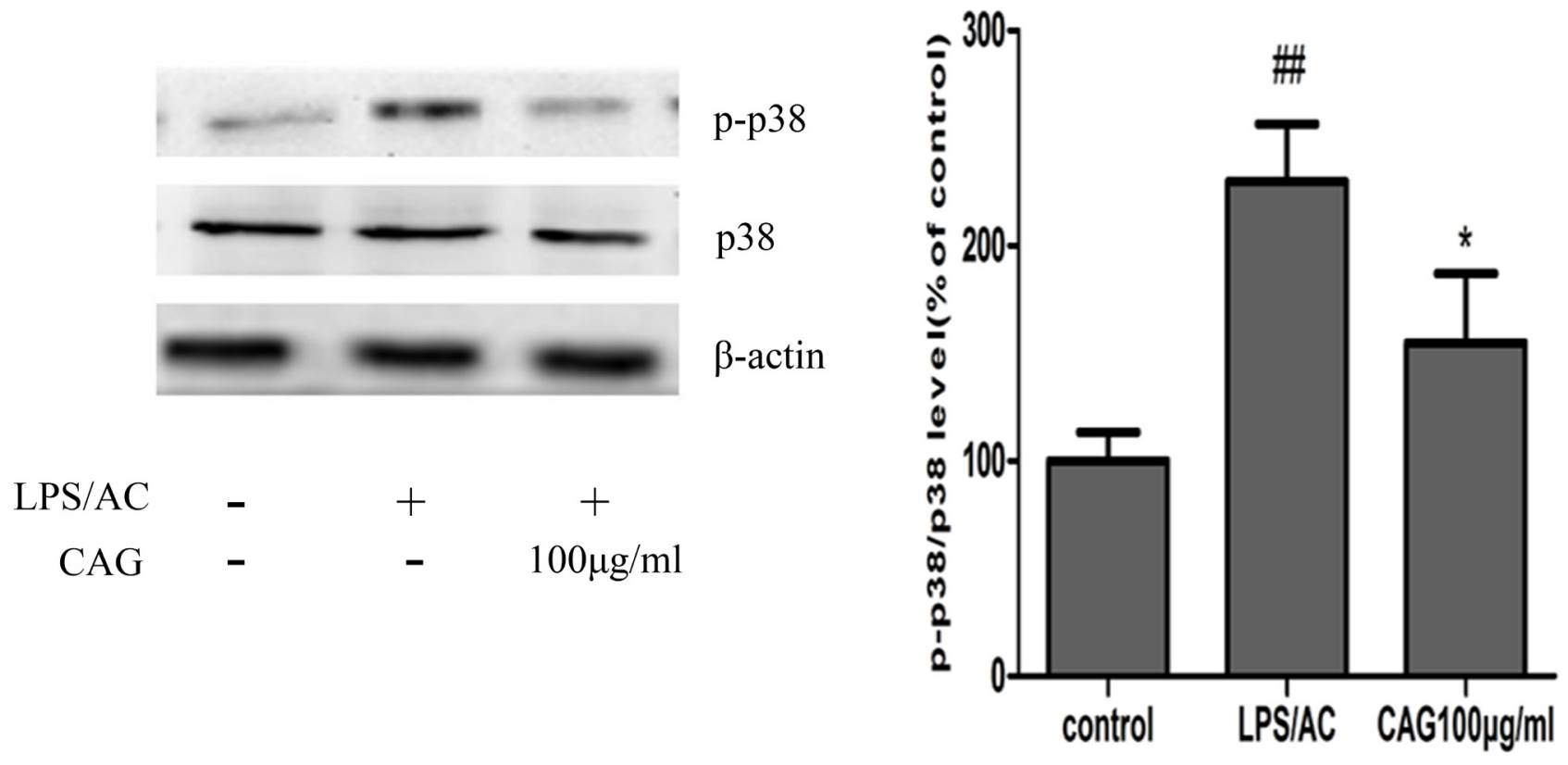

Figure 12: Effects of CAG treatment on p38 MAPK phosphorylation. Three groups of cells were tested; namely, the control, the model and the $100 \mu \mathrm{g} / \mathrm{mL}$ CAG treatment groups. ${ }^{*}<0.05,{ }^{\#}<0.01$ compared to the control group; $*<0.05, * *<0.01$ compared to the model group. 
Trypan blue. Cells were resuspended in DMEM and diluted to a final concentration of $5 \times 10^{5}$ cells $/ \mathrm{mL}$. The hepatocytes were seeded onto plates and then incubated at $37^{\circ} \mathrm{C}$ in a humidified incubator with an atmosphere of $5 \% \mathrm{CO}_{2}$.

\section{Establishment of a LPS/AC-induced liver injury model}

Cells were seeded onto 96-well plates at a density of $5 \times 10^{5}$ cells $/ \mathrm{mL}$ in $200 \mu \mathrm{L}$ of incubation culture medium for $24 \mathrm{~h}$. Then, the hepatocytes were incubated with LPS/ $\mathrm{AC}$ at concentrations of $30+60,30+80,30+100,30+$ 120 , and $30+140 \mu \mathrm{g} / \mathrm{mL}$ for $24 \mathrm{~h}$. MTT stock solution $(5 \mathrm{mg} / \mathrm{mL})$ was then applied to each of the wells, and the cells were incubated in a humidified atmosphere for $4 \mathrm{~h}$. The absorbance of the samples was measured using a microtiter plate reader at a dual wavelength mode of $490 \mathrm{~nm}$ and $655 \mathrm{~nm}$. Cell viability was calculated using the following equation: Cell viability $=($ Average $\mathrm{OD}$ of the treated wells - Average OD of the blank wells)/ (Average OD of the control wells - Average OD of the blank wells) $\times 100 \%$, where OD is the optical density.

\section{Evaluation of the protective effect of CAG on the LPS/AC-induced hepatocyte injury}

Hepatocytes were seeded onto 96-well plates at the same density for $24 \mathrm{~h}$. Different batches of cells were then incubated with CAG at concentrations of 1,10 , and $100 \mu \mathrm{g} / \mathrm{mL}$ for $24 \mathrm{~h}$. After incubation, the supernatant was discarded, and the cells were exposed to LPS/AC for $24 \mathrm{~h}$ at a concentration that induces death of $50 \%$ of the hepatocytes. Cell viability was measured as described above (Methods 2.3). The levels of AST and ALT in the cell culture supernatant were measured using commercial kits according to the manufacturer's protocols.

\section{Determination of MDA levels and SOD, GSH, and GSH-Px}

The cells were washed twice with $300 \mu \mathrm{L}$ of phosphate buffered saline (PBS, $\mathrm{pH}$ 7.4). The cells were detached using a sterilized scraper and lysed in $25 \mathrm{mmol} / \mathrm{L}$ Tris-HCl lysis buffer. The homogenate was then sonicated on ice (10-s pulses) and finally centrifuged at $13,000 \mathrm{~g}$ for $15 \mathrm{~min}$. The supernatant was collected and analyzed according to the procedures recommended by the manufacturers of the respective assay kits.

\section{ROS detection}

ROS levels were assessed using DCFH-DA. Briefly, after the cell medium was discarded, the cells were incubated with DCFH-DA for $20 \mathrm{~min}$ at $37^{\circ} \mathrm{C}$, washed three times with PBS, and then visualized under a fluorescence microplate.

\section{Measurement of caspase-3 activity}

The cells were isolated using trypsin, centrifuged $\left(4^{\circ} \mathrm{C}, 2,000 \mathrm{rpm}, 5 \mathrm{~min}\right)$, and resuspended in $150 \mu \mathrm{L}$ of a lysis buffer and $1.5 \mu \mathrm{L}$ DTT from a caspase- 3 colorimetric assay kit (KGA202, KeyGEN, China), placed on ice for $1 \mathrm{~h}$, and vortexed four times for $10 \mathrm{~s}$ each time. The cell suspension was centrifuged (10,000 rpm, $1 \mathrm{~min})$, and the supernatant was transferred to a $1.5-\mathrm{mL}$ centrifuge tube, which was then placed on ice. Approximately $50 \mu \mathrm{L}$ of a $2 \times$ reaction buffer and $5 \mu \mathrm{L}$ of the caspase- 3 substrate were added to each $50-\mu \mathrm{L}$ sample, incubated at $37^{\circ} \mathrm{C}$ in the dark for $4 \mathrm{~h}$, and then analyzed using a spectrophotometer at a wavelength of $405 \mathrm{~nm}$.

\section{Determination of apoptosis in primary chicken liver cells by flow cytometry (FCM)}

The detection kit (eBioscience, USA) employed in this study utilizes FITC-conjugated annexin V/PI. After treating with LPS/AC and CAG, the hepatocytes were dissociated by using $0.25 \%$ trypsin without EDTA (Solarbio, China) and collected as a suspension. A $100-\mu \mathrm{L}$ aliquot of the cell suspension was transferred to a 5 -mL culture tube, which was then mixed with $5 \mu \mathrm{L}$ of Annexin V-FITC and $5 \mu \mathrm{L}$ of propidium iodide. The cells were gently vortexed and incubated for $15 \mathrm{~min}$ at room temperature $\left(25^{\circ} \mathrm{C}\right)$ in the dark. Then, $400 \mu \mathrm{L}$ of $1 \times$ binding buffer were added to each tube and analyzed by FCM within $1 \mathrm{~h}$.

\section{Detection of apoptosis via Hoechst 33342 staining}

Primary chicken liver cells were cultured on a glass slide in 24-well plates. The cells were washed with PBS and then stained with Hoechst $33342(1 \mathrm{mg} / \mathrm{mL}$, Nanjing Jiancheng, China) for $10 \mathrm{~min}$. After two washes with PBS, the cells were examined using fluorescence microscopy.

\section{Relative quantification of target gene expression by real-time PCR (RT-PCR)}

Total RNA was extracted using TRIzol ${ }^{T M}$ (9108/9109 Takara, Japan) according to the manufacturer's instructions. cDNA synthesis was performed using $1 \mu \mathrm{g}$ of total RNA using a cDNA synthesis kit (RR047A Takara, Japan). The mRNA expression levels of caspase-3, bax, bcl-2, Fas, and actin were quantified by RT-PCR using a SYBR green premix according to the manufacturer's instructions (RR820A Takara, Japan). The thermal cycling conditions of the PCR assays were as follows: denaturation at $95^{\circ} \mathrm{C}$ for 3 min, followed by 40 cycles of denaturation at $95^{\circ} \mathrm{C}$ for $5 \mathrm{~s}$, primer annealing at $58^{\circ} \mathrm{C}$ for $30 \mathrm{~s}$, and primer extension at $72^{\circ} \mathrm{C}$ for $1 \mathrm{~min}$, with a final extension at $72^{\circ} \mathrm{C}$ for $6 \mathrm{~min}$. For each PCR product, a single narrow peak was obtained by 
melting curve analysis at a specific temperature. The relative expressions of the target genes were normalized to that of actin. The data were calculated using the $2^{-\Delta \Delta C t}$ method as described by the manufacturer and were expressed as a foldincrease over the indicated control groups.

\section{Relative quantification of target protein expression by western blot}

Hepatocytes were homogenized in RIPA buffer containing $50 \mathrm{mM}$ Tris/ $\mathrm{HCl}(\mathrm{pH}$ 8), $150 \mathrm{mM} \mathrm{NaCl}$, $1 \%$ non-idet-P40, $1 \%$ sodium deoxycholate, $0.1 \%$ SDS, $0.1 \mathrm{mM}$ DTT, $0.05 \mathrm{mM}$ PMSF, $0.002 \mathrm{mg} / \mathrm{mL}$ aprotinin, $0.002 \mathrm{mg} / \mathrm{mL}$ leupeptin, and $1 \mathrm{mM} \mathrm{NaVO}$. After centrifugation at $10,000 \mathrm{~g}$ for $20 \mathrm{~min}$, the protein concentration of the upper layer was determined by using a BCA kit according to the manufacturer's instructions. Approximately $50 \mu \mathrm{g}$ of the lysate was then resolved by SDS-PAGE and transferred to nitrocellulose membranes (Immobilon, Millipore Corp, Bedford, MA, USA). The membrane was blocked with TBST buffer (50 mM Tris$\mathrm{HCl}, 150 \mathrm{mM} \mathrm{NaCl}, 0.05 \%$ (w/v) Tween-20, $\mathrm{pH} 7.5$ ) containing $5 \%$ dried non-fat milk, then reacted with polyclonal caspase-3 (1: 1,000, Abcam, ab115183, UK), caspase-9 (Abcam, ab115161, UK), bax (EnoGene, E1A0083-1, China), Bcl-2 (BD, 610538, USA), and cyt c $\left(1: 100\right.$, Santa Cruz, sc-13560, USA) overnight at $4^{\circ} \mathrm{C}$. The membranes were washed with TBST thrice, each for $10 \mathrm{~min}$, and then incubated with a horseradish peroxidaselabeled antibody (1: 1,000 dilution) for $40 \mathrm{~min}$ at room temperature. After incubation, the membranes were thoroughly washed with TBST, and immunoreactive bands were detected by using ECL reagents.

\section{Transmission electron microscopy (TEM)}

For electron microscopy, the cells of every group earlier described were rapidly fixed in $2.5 \%$ glutaraldehyde in $0.1 \mathrm{M}$ sodium phosphate buffer $(\mathrm{pH} 7.2)$ for $3 \mathrm{~h}$ at $4^{\circ} \mathrm{C}$, and then later used in preparing TEM sections. Ultrathin sections were stained with $2 \%$ uranyl acetate and observed under a Hitachi transmission electron microscope.

\section{Mitochondrial membrane potential assay}

JC-1 kit was used to measure the mitochondrial membrane potential of the liver cells. After treatment with LPS/AC and CAG, cells were trypsinized, collected, centrifuged, resuspended with $0.5 \mathrm{~mL}$ DMEM and $0.5 \mathrm{~mL}$ JC-1 stain liquid, and incubated for $20 \mathrm{~min}$. Cells were washed two times with JC-1 stain buffer solution, then analyzed with FCM.

\section{Statistical analysis}

All data were expressed as the mean \pm standard deviation. One-way ANOVA was used for statistical comparisons. A $p$ value of $<0.05$ was deemed statistically significant. Graphs were plotted using Graphpad Prism 4 (GraphPAD Software, San Diego, CA, USA).

\section{CONFLICTS OF INTEREST}

None to declare.

\section{FUNDING}

The National Natural Science Foundation of China (grant no. 31572569) supported this study.

\section{REFERENCES}

1. Ulevitch RJ, Tobias PS. Recognition of gram-negative bacteria and endotoxin by the innate immune system. Curr Opin Immunol. 1999; 11:19-22. doi https://doi.org/10.1016/ S0952-7915(99)80004-1.

2. Jeong YI, Jung ID, Lee CM, Chang JH, Chun SH, Noh KT, Jeong SK, Shin YK, Lee WS, Kang MS, Lee SY, Lee JD, Park YM. The novel role of platelet-activating factor in protecting mice against lipopolysaccharide-induced endotoxic shock. PLoS One. 2009; 4:e6503. https://doi. org/10.1371/journal.pone.0006503.

3. Thirunavukkarasu C, Uemura T, Wang LF, Watkins SC, Gandhi CR. Normal rat hepatic stellate cells respond to endotoxin in LBP-independent manner to produce inhibitor(s) of DNA synthesis in hepatocytes. J Cell Physiol. 2005; 204:654-65. https://doi.org/10.1002/jcp.20366.

4. Michie HR, Manogue KR, Spriggs DR, Revhaug A, O'Dwyer S, Dinarello CA, Cerami A, Wolff SM, Wilmore DW. Detection of circulating tumor necrosis factor after endotoxin administration. N Engl J Med. 1988; 318:148186. https://doi.org/10.1056/NEJM198806093182301.

5. De Valle MB, Av Klinteberg V, Alem N, Olsson R, Björnsson E. Drug-induced liver injury in a Swedish University hospital out-patient hepatology clinic. Aliment Pharmacol Ther. 2006; 24:1187-95. https://doi.org/10.1111/ j.1365-2036.2006.03117.x.

6. Schiodt FV, Atillasoy E, Shakil AO, Schiff ER, Caldwell C, Kowdley KV, Stribling R, Crippin JS, Flamm S, Somberg KA, Rosen H, McCashland TM, Hay JE, Lee WM. Etiology and outcome for 295 patients with acute liver failure in the United States. Liver Transpl Surg. 1999; 5:29-34. doi https://doi.org/10.1002/lt.500050102.

7. Ostapowicz G, Fontana RJ, Schiødt FV, Larson A, Davern TJ, Han SH, McCashland TM, Shakil AO, Hay JE, Hynan L, Crippin JS, Blei AT, Samuel G, et al, and U.S. Acute Liver Failure Study Group. Results of a prospective study of acute liver failure at 17 tertiary care centers in the United States. Ann Intern Med. 2002; 137:947-54. doi https://doi. org/10.7326/0003-4819-137-12-200212170-00007.

8. Russo MW, Galanko JA, Shrestha R, Fried MW, Watkins P. Liver transplantation for acute liver failure from drug 
induced liver injury in the United States. Liver Transpl. 2004; 10:1018-23. https://doi.org/10.1002/1t.20204.

9. Lucena MI, Kaplowitz N, Hallal H, Castiella A, GarcíaBengoechea M, Otazua P, Berenguer M, Fernandez MC, Planas R, Andrade RJ. Recurrent drug-induced liver injury (DILI) with different drugs in the Spanish Registry: the dilemma of the relationship to autoimmune hepatitis. J Hepatol. 2011; 55:820-27. https://doi.org/10.1016/j.jhep.2010.12.041.

10. Meier Y, Cavallaro M, Roos M, Pauli-Magnus C, Folkers G, Meier PJ, Fattinger K. Incidence of drug-induced liver injury in medical inpatients. Eur J Clin Pharmacol. 2005; 61:135-43. https://doi.org/10.1007/s00228-004-0888-z.

11. Ghabril M, Chalasani N, Björnsson E. Druginduced liver injury: a clinical update. Curr Opin Gastroenterol. 2010; 26:222-26. https://doi.org/10.1097/ MOG.0b013e3283383c7c.

12. Leitner JM, Graninger W, Thalhammer F. Hepatotoxicity of antibacterials: pathomechanisms and clinical. Infection. 2010; 38:3-11. https://doi.org/10.1007/s15010-009-9179-z.

13. Yilmaz B, Ekız F, Coban S, Yüksel I, Yüksel O. Cefiximeinduced hepatotoxicity. Turk J Gastroenterol. 2011; 22:445. https://doi.org/10.4318/tjg.2011.0297.

14. Pauli-Magnus C, Meier PJ. Hepatobiliary transporters and drug-induced cholestasis. Hepatology. 2006; 44:778-87. https://doi.org/10.1002/hep.21359.

15. Jerzsele A, Nagy G, Lehel J, Semjen G. Oral bioavailability and pharmacokinetic profile of the amoxicillin-clavulanic acid combination after intravenous and oral gavage administration in broiler chickens. J Vet Pharmacol Ther. 2009; 32:506-09. https://doi.org/10.1111/j.13652885.2009.01066.x.

16. Hautekeete ML, Brenard R, Horsmans Y, Henrion J, Verbist L, Derue G, Druez P, Omar M, Kockx M, Hubens H, Haber I, Rahier J, Geubel AP. Liver injury related to amoxycillin-clavulanic acid: interlobular bile-duct lesions and extrahepatic manifestations. J Hepatol. 1995; 22:71-77. https://doi.org/10.1016/0168-8278(95)80262-2.

17. García Rodríguez LA, Stricker BH, Zimmerman HJ. Risk of acute liver injury associated with the combination of amoxicillin and clavulanic acid. Arch Intern Med. 1996; 156:1327-32. https://doi.org/10.1001/archinte.156.12.1327.

18. Fontana RJ, Shakil AO, Greenson JK, Boyd I, Lee WM. Acute liver failure due to amoxicillin and amoxicillin/ clavulanate. Dig Dis Sci. 2005; 50:1785-90. https://doi. org/10.1007/s10620-005-2938-5.

19. Robles M, Toscano E, Cotta J, Lucena MI, Andrade RJ. Antibiotic-induced liver toxicity: mechanisms, clinical features and causality assessment. Curr Drug Saf. 2010; 5:212-22. https://doi.org/10.2174/157488610791698307.

20. te Pas MF, Hulsegge I, Schokker D, Smits MA, Fife M, Zoorob R, Endale ML, Rebel JM. Meta-analysis of chicken-salmonella infection experiments. BMC Genomics. 2012; 13:146. https://doi.org/10.1186/14712164-13-146.
21. Yamamura Y, Kotaki H, Tanaka N, Aikawa T, Sawada Y, Iga $\mathrm{T}$. The pharmacokinetics of glycyrrhizin and its restorative effect on hepatic function in patients with chronic hepatitis and in chronically carbon-tetrachloride-intoxicated rats. Biopharm Drug Dispos. 1997; 18:717-25. https://doi. org/10.1002/(SICI)1099-081X(199711)18:8<717::AIDBDD54>3.0.CO;2-U.

22. Arase Y, Ikeda K, Murashima N, Chayama K, Tsubota A, Koida I, Suzuki Y, Saitoh S, Kobayashi M, Kumada H. The long term efficacy of glycyrrhizin in chronic hepatitis C patients. Cancer. 1997; 79:1494-500. https://doi. org/10.1002/(SICI)1097-0142(19970415)79:8<1494::AIDCNCR8>3.0.CO;2-B.

23. Sato H, Goto W, Yamamura J, Kurokawa M, Kageyama S, Takahara T, Watanabe A, Shiraki K. Therapeutic basis of glycyrrhizin on chronic hepatitis B. Antiviral Res. 1996; 30:171-77. https://doi.org/10.1016/0166-3542(96)00942-4.

24. Oh HM, Lee S, Park YN, Choi EJ, Choi JY, Kim JA, Kweon JH, Han WC, Choi SC, Han JK, Son JK, Lee $\mathrm{SH}$, Jun CD. Ammonium glycyrrhizinate protects gastric epithelial cells from hydrogen peroxide-induced cell death. Exp Biol Med (Maywood). 2009; 234:263-77. https://doi. org/10.3181/0805-RM-178.

25. Račková L, Jancinová V, Petríková M, Drábiková K, Nosál R, Stefek M, Kostálová D, Prónayová N, Kovácová M. Mechanism of anti-inflammatory action of liquorice extract and glycyrrhizin. Nat Prod Res. 2007; 21:1234-41. https:// doi.org/10.1080/14786410701371280.

26. Yim SB, Park SE, Lee CS. Protective effect of glycyrrhizin on 1-methyl-4-phenylpyridinium-induced mitochondrial damage and cell death in differentiated PC12 cells. J Pharmacol Exp Ther. 2007; 321:816-22. https://doi. org/10.1124/jpet.107.119602.

27. Ikeda M, Fujiyama S, Tanaka M, Sata M, Ide T, Yatsuhashi $\mathrm{H}$, Watanabe $\mathrm{H}$. Clinical features of hepatocellular carcinoma that occur after sustained virological response to interferon for chronic hepatitis C. J Gastroenterol Hepatol. 2006; 21:122-28. https://doi.org/10.1111/j.14401746.2005.04083.x.

28. Visavadiya NP, Narasimhacharya AV. Hypocholesterolaemic and antioxidant effects of Glycyrrhiza glabra (Linn) in rats. Mol Nutr Food Res. 2006; 50:1080-86. https://doi. org/10.1002/mnfr.200600063.

29. DelRaso NJ. In vitro methodologies for enhanced toxicity testing. Toxicol Lett. 1993; 68:91-99. https://doi. org/10.1016/0378-4274(93)90122-E.

30. Seglen PO. Preparation of isolated rat liver cells. Methods Cell Biol. 1976; 13:29-83. https://doi.org/10.1016/S0091679X(08)61797-5.

31. Morikawa A, Sugiyama T, Kato Y, Koide N, Jiang GZ, Takahashi K, Tamada Y, Yokochi T. Apoptotic cell death in the response of D-galactosamine-sensitized mice to lipopolysaccharide as an experimental endotoxic shock model. Infect Immun. 1996; 64:734-38. 
32. Furuya S, Kono H, Hara M, Hirayama K, Sun C, Fujii H. Interleukin $17 \mathrm{~A}$ plays a role in lipopolysaccharide/Dgalactosamine-induced fulminant hepatic injury in mice. J Surg Res. 2015; 199:487-93. https://doi.org/10.1016/j. jss.2015.05.060.

33. Gu L, Deng WS, Liu Y, Jiang CH, Sun LC, Sun XF, Xu Q, Zhou H. Ellagic acid protects Lipopolysaccharide/Dgalactosamine-induced acute hepatic injury in mice. Int Immunopharmacol. 2014; 22:341-45. https://doi. org/10.1016/j.intimp.2014.07.005.

34. Zhao J, Liu T, Ma L, Yan M, Zhao Y, Gu Z, Huang Y. Protective effect of acteoside on immunological liver injury induced by Bacillus Calmette-Guerin plus lipopolysaccharide. Planta Med. 2009; 75:1463-69. https:// doi.org/10.1055/s-0029-1185796.

35. Zhou J, Wang Q, Wang Q, Duan W. [Effects of norcantharidin on lipopolysaccharide-induced hepatocyte injury in vitro]. [Article in Chinese]. Zhong Nan Da Xue Xue Bao Yi Xue Ban. 2012; 37:285-89.

36. Ozturk IC, Ozturk F, Gul M, Ates B, Cetin A. Protective effects of ascorbic acid on hepatotoxicity and oxidative stress caused by carbon tetrachloride in the liver of Wistar rats. Cell Biochem Funct. 2009; 27:309-15. https://doi. org/10.1002/cbf.1575.

37. Winrow VR, Winyard PG, Morris CJ, Blake DR. Free radicals in inflammation: second messengers and mediators of tissue destruction. Br Med Bull. 1993; 49:506-22. https:// doi.org/10.1093/oxfordjournals.bmb.a072627.

38. Jaeschke H. Reactive oxygen and mechanisms of inflammatory liver injury: present concepts. J Gastroenterol Hepatol. 2011 (Suppl 1); 26:173-79. https://doi. org/10.1111/j.1440-1746.2010.06592.x.

39. Peng X, Jiang Y. Protective effects of Lactobacillus plantarum NDC 75017 against lipopolysaccharide-induced liver injury in mice. Inflammation. 2014; 37:1599-607. https://doi.org/10.1007/s10753-014-9886-1.

40. Simon HU, Haj-Yehia A, Levi-Schaffer F. Role of reactive oxygen species (ROS) in apoptosis induction. Apoptosis. 2000; 5:415-18. https://doi.org/10.1023/A:1009616228304.

41. Jaeschke H, Gujral JS, Bajt ML. Apoptosis and necrosis in liver disease. Liver Int. 2004; 24:85-89. https://doi. org/10.1111/j.1478-3231.2004.0906.x.

42. Kasahara I, Saitoh K, Nakamura K. Apoptosis in acute hepatic failure: histopathological study of human liver tissue using the tunel method and immunohistochemistry. J Med Dent Sci. 2000; 47:167-75.

43. Togo S, Makino H, Kobayashi T, Morita T, Shimizu T, Kubota T, Ichikawa Y, Ishikawa T, Okazaki Y, Hayashizaki
Y, Shimada H. Mechanism of liver regeneration after partial hepatectomy using mouse cDNA microarray. J Hepatol. 2004; 40:464-71. https://doi.org/10.1016/j. jhep.2003.11.005.

44. Green DR, Kroemer G. The pathophysiology of mitochondrial cell death. Science. 2004; 305:626-29. https://doi.org/10.1126/science.1099320.

45. Gustavsson T, Trane M, Moparthi VK, Miklovyte E, Moparthi L, Górecki K, Leiding T, Arsköld SP, Hägerhäll C. A cytochrome $\mathrm{c}$ fusion protein domain for convenient detection, quantification, and enhanced production of membrane proteins in Escherichia coli-expression and characterization of cytochrome-tagged Complex I subunits. Protein Sci. 2010; 19:1445-60. https://doi.org/10.1002/ pro.424.

46. Hüttemann M, Helling $\mathrm{S}$, Sanderson TH, Sinkler C, Samavati L, Mahapatra G, Varughese A, Lu G, Liu J, Ramzan R, Vogt S, Grossman LI, Doan JW, et al. Regulation of mitochondrial respiration and apoptosis through cell signaling: cytochrome c oxidase and cytochrome $\mathrm{c}$ in ischemia/reperfusion injury and inflammation. Biochim Biophys Acta. 2012; 1817:598-609. https://doi. org/10.1016/j.bbabio.2011.07.001.

47. Thornberry NA, Lazebnik Y. Caspases: enemies within. Science. 1998; 281:1312-16. https://doi.org/10.1126/ science.281.5381.1312.

48. Rodriguez J, Lazebnik Y. Caspase-9 and APAF-1 form an active holoenzyme. Genes Dev. 1999; 13:3179-84. https:// doi.org/10.1101/gad.13.24.3179.

49. Wolter KG, Hsu YT, Smith CL, Nechushtan A, Xi XG, Youle RJ. Movement of Bax from the cytosol to mitochondria during apoptosis. J Cell Biol. 1997; 139:1281-92. https://doi.org/10.1083/jcb.139.5.1281.

50. King KL, Cidlowski JA. Cell cycle regulation and apoptosis. Annu Rev Physiol. 1998; 60:601-17. https://doi. org/10.1146/annurev.physiol.60.1.601.

51. Kluck RM, Bossy-Wetzel E, Green DR, Newmeyer DD. The release of cytochrome c from mitochondria: a primary site for Bcl-2 regulation of apoptosis. Science. 1997; 275:113236. https://doi.org/10.1126/science.275.5303.1132.

52. Nebreda AR, Porras A. p38 MAP kinases: beyond the stress response. Trends Biochem Sci. 2000; 25:257-60. https:// doi.org/10.1016/S0968-0004(00)01595-4.

53. Schieven GL. The biology of p38 kinase: a central role in inflammation. Curr Top Med Chem. 2005; 5:921-28. https://doi.org/10.2174/1568026054985902. 